\title{
Coupling physics and biogeochemistry thanks to high-resolution observations of the phytoplankton community structure in the northwestern Mediterranean Sea
}

\author{
Pierre Marrec $^{1}$, Gérald Grégori ${ }^{1}$, Andrea M. Doglioli ${ }^{1}$, Mathilde Dugenne ${ }^{1}$, Alice Della Penna ${ }^{1}$, Nagib Bhairy ${ }^{1}$, \\ Thierry Cariou ${ }^{2}$, Sandra Hélias Nunige ${ }^{1}$, Soumaya Lahbib ${ }^{1}$, Gilles Rougier $^{1}$, Thibaut Wagener ${ }^{1}$, and \\ Melilotus Thyssen ${ }^{1}$ \\ ${ }^{1}$ Aix Marseille Univ, Université de Toulon, CNRS, IRD, MIO UM 110, 13288, Marseille, France \\ ${ }^{2}$ Sorbonne Universités, UPMC Univ Paris 06, CNRS, Fédération de Recherche (FR2424), Station Biologique \\ de Roscoff, 29680, Roscoff, France
}

Correspondence: Pierre Marrec (pierre.marrec@mio.osupytheas.fr)

Received: 4 August 2017 - Discussion started: 22 August 2017

Revised: 24 January 2018 - Accepted: 25 January 2018 - Published: 15 March 2018

\begin{abstract}
Fine-scale physical structures and ocean dynamics strongly influence and regulate biogeochemical and ecological processes. These processes are particularly challenging to describe and understand because of their ephemeral nature. The OSCAHR (Observing Submesoscale Coupling At High Resolution) campaign was conducted in fall 2015 in which a fine-scale structure (1-10 km/1-10 days) in the northwestern Mediterranean Ligurian subbasin was pre-identified using both satellite and numerical modeling data. Along the ship track, various variables were measured at the surface (temperature, salinity, chlorophyll $a$ and nutrient concentrations) with ADCP current velocity. We also deployed a new model of the CytoSense automated flow cytometer (AFCM) optimized for small and dim cells, for near real-time characterization of the surface phytoplankton community structure of surface waters with a spatial resolution of a few kilometers and an hourly temporal resolution. For the first time with this optimized version of the AFCM, we were able to fully resolve Prochlorococcus picocyanobacteria in addition to the easily distinguishable Synechococcus. The vertical physical dynamics and biogeochemical properties of the studied area were investigated by continuous high-resolution CTD profiles thanks to a moving vessel profiler (MVP) during the vessel underway associated with a high-resolution pumping system deployed during fixed stations allowing sampling of the water column at a fine resolution (below $1 \mathrm{~m}$ ). The observed fine-scale feature presented a cyclonic structure with a relatively cold core surrounded by warmer waters. Surface
\end{abstract}

waters were totally depleted in nitrate and phosphate. In addition to the doming of the isopycnals by the cyclonic circulation, an intense wind event induced Ekman pumping. The upwelled subsurface cold nutrient-rich water fertilized surface waters and was marked by an increase in Chl $a$ concentration. Prochlorococcus and pico- and nano-eukaryotes were more abundant in cold core waters, while Synechococcus dominated in warm boundary waters. Nanoeukaryotes were the main contributors $(>50 \%)$ in terms of pigment content (red fluorescence) and biomass. Biological observations based on the mean cell's red fluorescence recorded by AFCM combined with physical properties of surface waters suggest a distinct origin for two warm boundary waters. Finally, the application of a matrix growth population model based on high-frequency AFCM measurements in warm boundary surface waters provides estimates of in situ growth rate and apparent net primary production for Prochlorococcus $\left(\mu=0.21 \mathrm{~d}^{-1}, \mathrm{NPP}=0.11 \mathrm{mg} \mathrm{Cm}^{-3} \mathrm{~d}^{-1}\right)$ and Synechococ cus $\left(\mu=0.72 \mathrm{~d}^{-1}, \mathrm{NPP}=2.68 \mathrm{mg} \mathrm{Cm}^{-3} \mathrm{~d}^{-1}\right)$, which corroborate their opposite surface distribution pattern. The innovative adaptive strategy applied during OSCAHR with a combination of several multidisciplinary and complementary approaches involving high-resolution in situ observations and sampling, remote-sensing and model simulations provided a deeper understanding of the marine biogeochemical dynamics through the first trophic levels. 


\section{Introduction}

Despite representing only $0.2 \%$ of the global photosynthetically active carbon (C) biomass, phytoplankton accounts for about half of the global primary productivity on Earth (Falkowski et al., 1998; Field et al., 1998). It forms the basis of the marine food web and exerts a major control on global biogeochemical cycles. In the context of global change, mainly due to the rise in anthropogenic atmospheric $\mathrm{CO}_{2}$ (IPCC, 2013), marine phytoplankton plays a fundamental role in the global $\mathrm{C}$ cycle by photosynthetically fixing $\mathrm{CO}_{2}$ and exporting it into the ocean's interior by the biological pump (De La Rocha and Passow, 2007). Phytoplankton community structures are highly heterogeneous over the ocean in terms of assemblage, physiology and taxonomy (Barton et al., 2010; De Vargas et al., 2015). Phytoplankton cell volume spans more than 9 orders of magnitude (Marañón et al., 2015), from Prochlorococcus cyanobacteria $\left(\sim 10^{-1} \mu \mathrm{m}^{3}\right)$ to the largest diatoms $\left(>10^{8} \mu \mathrm{m}^{3}\right)$. Phytoplankton diversity is primarily controlled by environmental factors such as temperature, nutrients, light availability, vertical stability, and predation, which lead to a biogeography of phytoplankton's diversity landscape (Lévy et al., 2015). The heterogeneity and the fine-scale variability of phytoplankton abundance have been observed and described from the 1970s (Platt, 1972; Denman et al., 1976), but the community structure variability on this scale remained uncharted at this time. While on a basin scale the phytoplankton community structure is relatively well constrained, on smaller scales both modeling (Lévy et al., 2001; Clayton et al., 2013; Lévy et al., 2014; d'Ovidio et al., 2015) and observation (Claustre et al., 1994; d'Ovidio et al., 2010; Clayton et al., 2014; Martin et al., 2015; Cotti-Rausch et al., 2016) studies have revealed during the last decades that phytoplankton community structure exhibits strong variability (Levy et al., 2015).

The term "fine-scale" is generally used to refer to the ocean dynamics features occurring on scales smaller than about $100 \mathrm{~km}$; consequently, the term includes (i) a fraction of the mesoscale processes (e.g., large coherent eddies), with scales close to the first internal Rossby radius, and (ii) the submesoscale processes, with scales smaller than the first internal Rossby radius (e.g., intense vortices, fronts and filaments). The physical dynamics on that scale strongly influence and regulate biogeochemical and ecological processes (McGillicuddy et al., 1998; Levy and Martin, 2013; McGillicuddy, 2016). This can have a significant impact on primary productivity (Oschlies and Garçon, 1998; Mahadevan, 2016) and thus on the biological C pump (Levy et al., 2013) and associated export (Siegel et al., 2016). Mesoscale eddies modify the vertical structure of the water column: cyclones and anti-cyclones, respectively, shoal and deepen isopycnals (McGillicuddy et al., 1998). Eddy pumping may have a significant biogeochemical impact in oligotrophic areas (Falkowski et al., 1991): shoaling isopycnals in the center of a mesoscale cyclonic eddy can stimulate phytoplank- ton productivity by lifting nutrients into the euphotic zone. Eddy stirring and trapping further influence biogeochemical and ecological processes (McGillicuddy, 2016, for a review). Submesoscale dynamics enhance the supply of nutrients in the euphotic zone in nutrient depleted areas and also influence the light exposure of phytoplankton by modifying the density gradient in the surface layer, which contribute significantly to phytoplankton production (Mahadevan, 2016) and community structure variability (Cotti-Rausch et al., 2016). The underlying biogeochemical submesoscale processes are particularly challenging to describe and understand because of their ephemeral nature. For the moment, submesoscale dynamics have been predominantly investigated through the analysis of numerical simulation. The lack of in situ observations at an appropriate spatio-temporal resolution makes the integration of these in situ data with the model simulations difficult, and it still remains unclear how these processes affect the global state of the ocean (Mahadevan, 2016).

The efficient study of fine-scale structures and their associated physical-biological-biogeochemical mechanisms requires the use of a combination of several complementary approaches involving in situ observations and sampling, remote-sensing and model simulations (Pascual et al., 2017). High-resolution measurements are mandatory to assess the mechanisms controlling the fine-scale biophysical interactions. They are now available thanks to the recent progress in biogeochemical sensor developments, the combination of ship-based measurements and autonomous platforms, and innovative adaptive approaches. The OSCAHR project (Observing Submesoscale Coupling At High Resolution, PIs: A. M. Doglioli and G. Grégori) aims to study the influence of fine-scale physical dynamics on the biogeochemical processes, phytoplankton community structure and dynamics at high resolution. In the present study the terms "high resolution" and "fine-scale" aim to describe observations and mechanisms, respectively.

During the OSCAHR cruise, novel platforms for coupling physical-biological-biogeochemical observations and sampling the ocean surface layer at a high spatial and temporal resolution were coupled with real-time analyses of satellite ocean color imagery and altimetry. In this article, we first describe the hydrological structure and dynamics of the studied feature based on satellite data and continuous sea surface measurements. Then we address the corresponding phytoplankton community structure and distribution based on analyses performed at the single-cell level and at high spatiotemporal resolution in an autonomous way. Moreover, we also present the fine-scale vertical variability of the phytoplankton community structure in various stations within and outside the studied structure, resulting in a three-dimensional dataset for the investigation of the physical driving mechanisms acting on the phytoplankton community structure. Finally, thanks to the outstanding potential of single-cell analysis performed by automated high-resolution flow cytometry, we estimate in situ growth rates and address the appar- 
ent primary productivity of the two dominant phytoplankton species (in terms of abundances), Prochlorococcus and Synechococcus.

\section{Materials and methods}

\subsection{OSCAHR outlines}

The OSCAHR cruise was carried out between 29 October 2015 and 6 November 2015 in the western Ligurian subbasin onboard R/V Téthys II (Doglioli, 2015). A first leg sampled the coastal waters, and a second one was dedicated to offshore waters in a $>1000 \mathrm{~m}$ water column area. The present study focuses on the second leg held from 3 November to 6 November (Fig. 1). The cruise strategy used an adaptive approach based on the near-real-time analysis of both satellite and numerical modeling data to identify dynamical features of interest and to follow their evolution. Several satellite datasets were exploited during the campaign to guide the cruise using the SPASSO software package (Software Package for an Adaptative Satellite-based Sampling for Ocean campaigns, http://www.mio.univ-amu.fr/ SPASSO/) following the same approach of previous cruises such as LATEX (Doglioli et al., 2013; Petrenko et al., 2017) and KEOPS2 (d'Ovidio et al., 2015). SPASSO was also used after the cruise in order to extend the spatial and temporal vision of the in situ observations. We sampled a fine-scale dynamical structure characterized by a patch of cold surface water surrounded by warm waters. We recorded physical, biological and chemical data at high frequency (minute to hourly scale) with a combination of classical (thermosalinograph (TSG), discrete surface sampling) and innovative (automated high-frequency flow cytometry (AFCM), MVP) methods. Regular fixed station measurements (classical conductivity, temperature, depth (CTD) profiles and sampling at high vertical resolution (at a meter scale)) were also performed at strategic sampling sites.

\subsection{Satellite and model products}

We used the altimetry-derived (i.e., geostrophic) velocities distributed by AVISO as a multi-satellite Mediterranean regional product (http://www.aviso.altimetry.fr) on a daily basis with a spatial resolution of $1 / 4^{\circ}$. Sea surface temperature (SST, levels 3 and $4,1 \mathrm{~km}$ resolution) and Chl $a$ concentrations (level $3,1 \mathrm{~km}$ resolution, MODIS-Aqua and NPP-VIIRS sensors) were provided by CMEMS (Copernicus Marine Environment Monitoring Service, htpp://marine.copernicus.eu). Following d'Ovidio et al. (2015), Eulerian and Lagrangian diagnostics were performed on the altimetry-derived currents. The Chl $a$ product is optimized to work in "case 1 waters" (Morel et al., 2006), i.e., open ocean conditions where the optical signal is dominated by phytoplankton. The WRF (Weather Research and Forecasting, Skamarock et al., 2008) atmospheric numerical model provided meteorological forecast (wind speed and direction, irradiance). WRF has been implemented at the $\mathrm{Ob}$ servatory of Universe Sciences, Institut Pytheas (Marseille), as an operational model. Ekman pumping was calculated from the curl of the wind stress: $w=\operatorname{curl}(\tau / \rho \cdot f)$, where $w$ is an estimate of the vertical velocity ( $w>0$ refers to vertical velocity), $\rho$ is the density of the water, here considered $\rho=$ $1028 \mathrm{~kg} \mathrm{~m}^{3}$, and $f$ is the Coriolis parameter that is variable with latitude and in the region of study is $\sim 10^{-4} \mathrm{rad} \mathrm{s}^{-1}$.

\subsection{Nutrients and Chl $a$ analysis}

Nutrient samples were collected in $20 \mathrm{~cm}^{3}$ high-density polyethylene bottles poisoned with $\mathrm{HgCl}_{2}$ to a final concentration of $20 \mathrm{mg} \mathrm{dm}^{-3}$ and stored at $4{ }^{\circ} \mathrm{C}$ before being analyzed in the laboratory a few months later. Nutrient concentrations were determined using a Seal AA3 auto-analyzer following the method of Aminot and Kérouel (2007) with analytical precision of $0.01 \mu \mathrm{mol} \mathrm{dm}{ }^{-3}$ and quantification limits of $0.02,0.05$ and $0.30 \mu \mathrm{mol} \mathrm{dm}{ }^{-3}$ for phosphate, nitrate (and nitrite) and silicate, respectively.

To determine Chl $a$ concentrations, $500 \pm 20 \mathrm{~cm}^{3}$ of seawater were filtered through $25 \mathrm{~mm}$ glass-fiber pyrolyzed filters (Whatman ${ }^{\circledR} \mathrm{GF} / \mathrm{F}$ ) and immediately frozen at $-20^{\circ} \mathrm{C}$. Filters were placed in glass tubes containing $5 \mathrm{~cm}^{3}$ of pure methanol and allowed to extract for $30 \mathrm{~min}$ as described by Aminot and Kérouel (2007). Fluorescence of the extract was determined by using a Turner Fluorometer AU10 equipped with the Welschmeyer kit to avoid chlorophyll b interference (Welschmeyer, 1994). The fluorometer was zeroed with methanol turbidity blank. The detection limit was $0.01 \mu \mathrm{g} \mathrm{dm}^{-3}$. Calibration was performed using a pure $\mathrm{Chl} a$ standard (Sigma Aldrich ${ }^{\circledR}$, ref: C5753, pure spinach chlorophyll).

\subsection{Benchtop flow cytometry}

Seawater samples collected from the Niskin bottles were prefiltered through a $100 \mu \mathrm{m}$ mesh size net to prevent any clogging of the flow cytometer. Cryovials $\left(5 \mathrm{~cm}^{3}\right)$ were filled with subsamples that were preserved with glutaraldehyde $0.2 \%$ final concentration for ultraphytoplankton analysis. Samples were then rapidly frozen in and stored in liquid nitrogen until analysis at the PRECYM flow cytometry platform of the institute. In the laboratory, cryovials were rapidly thawed at room temperature and analyzed using the FACSCalibur flow cytometer (BD Biosciences ${ }^{\circledR}$ ) of PRECYM. This flow cytometer is equipped with a blue $(488 \mathrm{~nm})$ air-cooled argon laser and a red $(634 \mathrm{~nm})$ diode laser. For each particle analyzed (cell), five optical parameters were recorded: forward and right angle light scatter, and green (515-545 nm), orange $(564-606 \mathrm{~nm})$ and red $(653-669 \mathrm{~nm})$ fluorescence wavelength ranges. Data were collected using the CellQuest software (BD Biosciences ${ }^{\circledR}$ ). The analysis and identification of ultraphytoplankton groups were performed a posteriori us- 

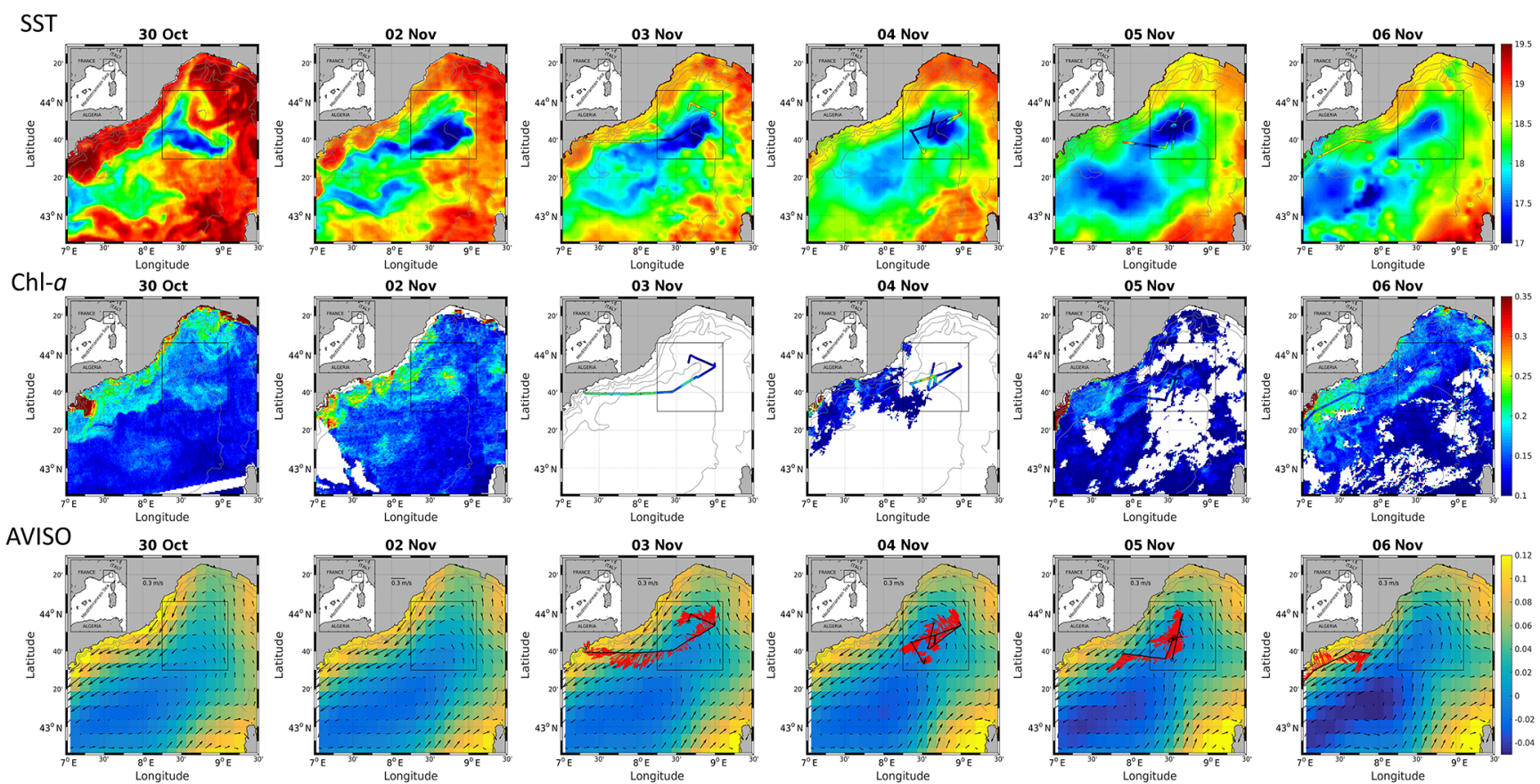

Figure 1. Sea surface temperature (SST, in ${ }^{\circ} \mathrm{C}$ ), $\mathrm{Chl} a$ concentration (in $\mu \mathrm{g} \mathrm{dm}{ }^{-3}$ ) and AVISO altimetry (in $\mathrm{cm}$ ) and derived current intensity $\left(\mathrm{m} \mathrm{s}^{-1}\right)$ and direction in the Ligurian subbasin from 30 October to 6 November. The black box represents the study area. From 3 November to 6 November, SST and Chl $a$ continuous surface measurements were superimposed on the satellite products and ADCP currents were represented in the AVISO products.

ing SUMMIT v4.3 software (Beckman Coulter). For each sample the runtime of the flow cytometer was set at $5 \mathrm{~min}$. The sample flow rate was about $100 \mathrm{~mm}^{-3} \mathrm{~min}^{-1}$ (corresponding to the "Hi" flow rate of the flow cytometer).

Various ultraphytoplankton groups were optically resolved without any staining on the basis of their light scatter and fluorescence properties (defined below in Sect. 3). Separation of picoeukaryotes and nanophytoplankton was performed by adding $2 \mu \mathrm{m}$ yellow-green fluorescent cytometry microspheres (Fluoresbrite YG $2 \mu \mathrm{m}$, Polyscience Inc.) to the samples. Trucount ${ }^{\mathrm{TM}}$ calibration beads (Becton Dickinson Biosciences) were also added to the samples as an internal standard both to monitor the instrument stability and to determine the volume analyzed by the instrument. This is mandatory to compute the cell abundances.

\subsection{Underway surface measurements}

The in situ velocity of the currents was measured by a hull-mounted RDI Ocean Sentinel $75 \mathrm{kHz}$ ADCP (acoustic Doppler current-meter profiler). The configuration used during the whole cruise was 60 cells, $8 \mathrm{~m}$ depth beams, and 1 min averaged. The depth range extended from 18.5 to $562.5 \mathrm{~m}$.

The onboard surface-water flow-through system pumped seawater at $2 \mathrm{~m}$ in depth with a flow rate carefully maintained at $60 \mathrm{dm}^{3} \mathrm{~min}^{-1}$. The TSG, a SeaBird SBE21, ac- quired sea surface temperature (SST) and salinity (SSS) data every minute during the whole cruise. A Turner Designs fluorometer (10-AU-005-CE) recorded simultaneously sea surface fluorescence. In order to validate the salinity measurements computed from conductimetry, discrete salinity samples were performed on a daily basis before, during and after the campaign. They were measured on a PortaSal salinometer at the SHOM (Service Hydrographique et Oceanographique de la Marine) with a precision of 0.002 . A 1:1 relationship between TSG and analyzed salinity was obtained $\left(R^{2}=0.97, n=31\right)$ with a mean difference of 0.000 and a SD of the residuals of 0.018. Surface water samples were collected every $20 \mathrm{~min}$ from the TSG water outflow for the determination of nitrate, nitrite, phosphate and silicate concentrations (Sect. 2.3); in total, 177 surface samples were obtained. Measurements for Chl $a$ (Sect. 2.3) were collected randomly during the day and the night, leading to a total of 41 samples collected from the flow-through system. The TSG fluorescence signal was converted to Chl $a$ concentration values thanks to a comparison with $\mathrm{Chl} a$ analysis showing a significant correlation between fluorescence and Chl $a$ with a $R^{2}$ of 0.50 ( $p$ value $<0.05$ ). As Chl $a$ values obtained during OSCAHR were low (0.08 to $0.42 \mu \mathrm{g} \mathrm{dm}{ }^{-3}$, with a mean value of $0.15 \mu \mathrm{g} \mathrm{dm}^{-3}$ ), and considering the effect of fluorescence quenching, getting such a correlation was quite reasonable. 

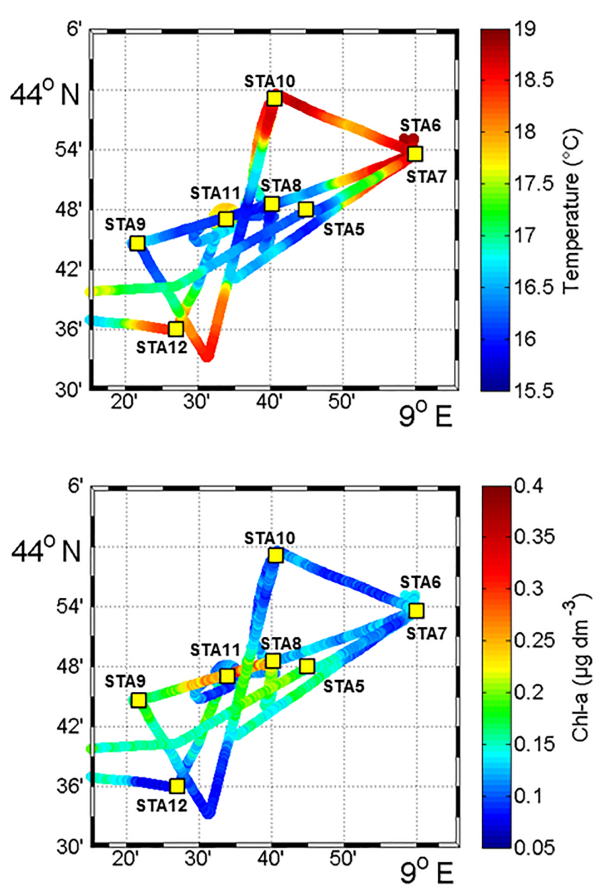

Figure 2. Sea surface temperature (SST, in ${ }^{\circ} \mathrm{C}$ ) and $\mathrm{Chl} a$ concentrations $\left(\mu \mathrm{g} \mathrm{dm}^{-3}\right)$ obtained from fluorescence continuous surface measurements from 3 November to 6 November during the OSCAHR campaign and fixed station locations (STA5 to STA12). This study area corresponds to the black box represented in Fig. 1.

The CytoSense, an automated flow cytometer (AFCM) designed by the CytoBuoy, b.v. company (NL), analyzed every 20 min samples isolated from the sea surface continuous flow-through system of the TSG. The AFCM used in this study was specially designed to analyze the pulse shapes of a wide range of phytoplankton size $(<1-800 \mu \mathrm{m}$ in width and several $\mathrm{mm}$ in length) and abundance (within the $\sim 0.5$ to the $\sim 4.5 \mathrm{~cm}^{3}$ analyzed). The analyzed seawater was pumped with a calibrated (weighing method) peristaltic pump from a discrete intermediate container, subsampling the continuous flow-through seawater into a $300 \mathrm{~cm}^{3}$ volume to minimize the spatial extent during the AFCM analyzing time. A sheath loop $(\mathrm{NaCl}$ solution $(35 \%)$ filtered on $0.2 \mu \mathrm{m})$ was used to separate, align and drive the particles to the light source and was continuously recycled using a set of two $0.1 \mu \mathrm{m}$ filters $\left(\right.$ Mintech ${ }^{\circledR}$ fiber Flo $0.1 \mu \mathrm{m}$ ), completed with an additional carbon filter (PALL ${ }^{\circledR}$ Carbon filter) to reduce the background signal from the seawater and remove colloidal material. The sheath flow rate was $1.3 \mathrm{~cm}^{3} \mathrm{~s}^{-1}$. In the flow cell, each particle was intercepted by a laser beam (OBIS ${ }^{\circledR}$ laser, $488 \mathrm{~nm}, 150 \mathrm{~mW}$ ) and the generated optical pulse shape signals were recorded. The light scattered at $90^{\circ}$ (sideward scatter, SWS) and fluorescence emissions were separated by a set of optical filters (SWS $(488 \mathrm{~nm})$, orange fluorescence (FLO, 552-652 nm) and red fluorescence (FLR, $>652 \mathrm{~nm}$ )) and collected on photomultiplier tubes. The for- ward scatter (FWS) signal was collected onto two photodiodes to recover left and right signals of the pulse shape. Each particle passes at a speed of $2 \mathrm{~m} \mathrm{~s}^{-1}$ along the laser beam width $(5 \mu \mathrm{m})$ with a data recording frequency of $4 \mathrm{MHz}$, generating optical pulse shapes used as a diagnostic tool to discriminate phytoplankton groups. Two distinct protocols were run sequentially every $20 \mathrm{~min}$, the first one targeted autotrophic picophytoplankton with FLR trigger level fixed at $5 \mathrm{mV}$, sample flow rate at $5.0 \mathrm{~mm}^{3} \mathrm{~s}^{-1}$ for 3 min, resulting in $\sim 0.5 \mathrm{~cm}^{3}$ analyzed samples. Two main groups, Prochlorococcus and Synechococcus, were optimally resolved and adequately counted using this first protocol. Synechococcus are easily detectable by flow cytometry due to the bright orange fluorescence emitted by phycoerythrin during the excitation by the blue $488 \mathrm{~nm}$ laser beam of the flow cytometer. Prochlorococcus, which are smaller than Synechococcus, are characterized by very dim red fluorescence induced by $\mathrm{Chl} a$. The second protocol dedicated to the analysis of nanoand microphytoplankton was triggered on FLR at $30 \mathrm{mV}$, sample flow rate was fixed at $10 \mathrm{~mm}^{3} \mathrm{~s}^{-1}$ for $10 \mathrm{~min}$, resulting in $\sim 4.5 \mathrm{~cm}^{3}$ analyzed samples. Using this configuration, more accurate abundances of these less abundant microorganisms were obtained as the smallest and most abundant cells (Prochlorococcus for instance) were not considered. Phytoplankton groups were resolved using CytoClus ${ }^{\circledR}$ software generating several two-dimensional cytograms of retrieved information from the 4 pulse shapes curves (FWS, SWS, FLO, FLR) obtained for every single cell, mainly the area under the curve and the maximum of the pulse shape signal. Groups' abundances (cells cm${ }^{-3}$ ), mean (a.u. cell ${ }^{-1}$, a.u. standing for arbitrary units) and sum (product of mean properties per group abundances, a.u. $\mathrm{cm}^{-3}$ ) of optical pulse shapes were processed with the software to assess their inherent dynamics. Up to 150 pictures of microphytoplankton were collected during the FLR $30 \mathrm{mV}$ acquisition by an image-in-flow camera mounted upward the flow cell. FWS scatter signals of silica beads $(0.4,1.0,1.49,2.01,2.56,3.13$, $4.54,5.02,7.27 \mu \mathrm{m}$ non functionalized silica microspheres Bangs Laboratories, Inc.) were used to convert light scatter to equivalent spherical diameter (ESD) and biovolume. A power law relationship $(\log ($ Size $)=0.309 \cdot \log ($ FWS $)-$ 1.853) allowed the conversion of the FWS signal into cell size $\left(n=17, R^{2}=0.94\right)$. The stability of the optical unit and the flow rates were checked using Beckman Coulter Flowcheck ${ }^{\mathrm{TM}}$ fluorospheres $(2 \mu \mathrm{m})$ before, during and after installation.

\subsection{Vertical sampling}

A moving vessel profiler, MVP200 ODIM Brooke Ocean, equipped with a MSFFF I (Multi Sensor Free Fall Fish type I) containing an AML microCTD was deployed. The MVP casts were run from sea surface to $300 \mathrm{~m}$ in depth during the vessel underway at a mean speed of 6 knots with continuous acquisition of temperature and salinity. Along most 

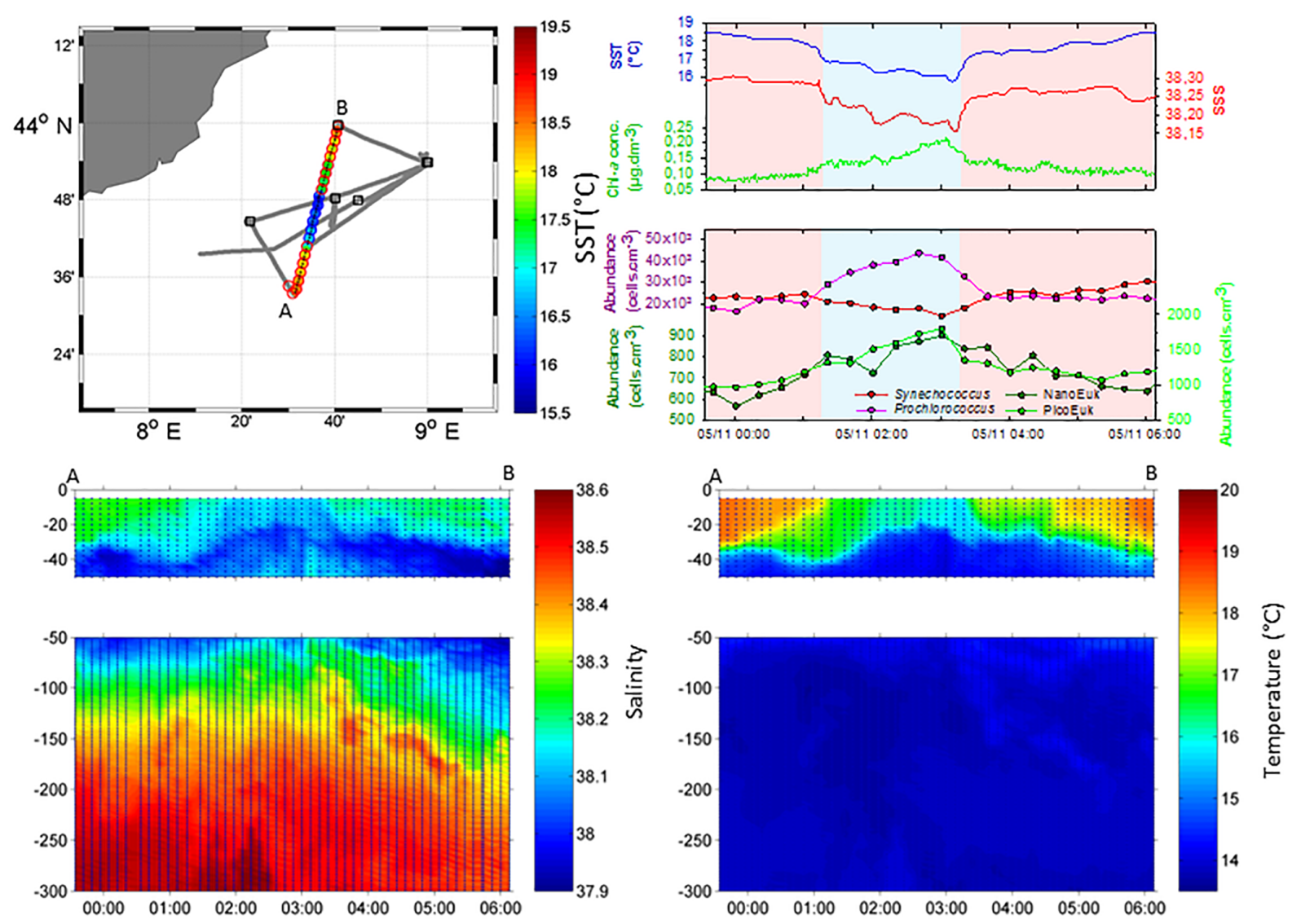

Figure 3. Continuous vertical profiles of salinity and temperature from the surface to $300 \mathrm{~m}$ in depth between points A and B from 00:00 to 06:00 (local time) on 5 November. Associated SST (in ${ }^{\circ} \mathrm{C}$ ), SSS and Chl $a$ concentration (in $\mu \mathrm{g} \mathrm{dm}^{-3}$ ) from continuous surface measurements and abundances (in cell $\mathrm{cm}^{-3}$ ) of Prochlorococcus, Synechococcus, picoeukaryotes (PicoEuk) and nanoeukaryotes (NanoEuk).

of the campaign route, vertical profiles of temperature and salinity were obtained during the nearly vertical free fall with a temporal resolution of 8-10 min, corresponding to a spatial resolution of $\sim 1 \mathrm{~km}$. Salinity and temperature data acquired near the surface $(\sim 5 \mathrm{~m})$ with the MVP were compared to the data acquired from the onboard TSG. MVP temperature and salinity values were significantly correlated with the continuous underway measurements with a $1: 1$ relationship, $R^{2}$ of 0.99 and 0.84 and root mean square error (RMSE) of residuals of $0.07^{\circ} \mathrm{C}$ and 0.02 for temperature and salinity, respectively.

A total of eight fixed stations were performed (Fig. 2) and used to collect biogeochemical information and to validate the deployment of the MVP. For each station, a CTD rosette cast down to $300 \mathrm{~m}$ recorded temperature, salinity and fluorescence profiles. At Station 11, the water column properties down to $1000 \mathrm{~m}$ were investigated with this CTD rosette instrument. The CTD rosette was equipped with a 12 Niskin bottle $\left(12 \mathrm{dm}^{3}\right)$ SBE32 Carousel water sampler and carried a CTD SBE911+ for temperature and salinity, a Chelsea Aquatracka III fluorimeter and a QCP-2350 (cosinus collector) for PAR measurements. Samples for nutrients and phy- toplankton groups using benchtop flow cytometry (Sect. 2.4) were collected from the surface to $1000 \mathrm{~m}$ in depth.

For stations 5 to 11 (Fig. 2), an innovative system of highresolution seawater sampling down to $35 \mathrm{~m}$ (PASTIS_HVR - Pumping Advanced System To Investigate Seawater with High Vertical Resolution) was deployed. Seawater samples were collected using a Teflon pump (AstiPure ${ }^{\mathrm{TM}}$ II High Purity Bellows Pumps - flow rate $=30 \mathrm{dm}^{3} \mathrm{~min}^{-1}$ ) connected to a polyethylene (PE) tube fixed to the frame at the level of the pressure sensor of a Seabird SBE19+ CTD and a WetLab WETstar WS3S fluorimeter. The depth of the sampling was defined as the mean depth recorded by the pressure sensor with a vertical resolution of 0.1 to $1 \mathrm{~m}$ (depending on the sea state). The SBE19+ CTD offered precisions for temperature and computed salinity of $0.005^{\circ} \mathrm{C}$ and 0.002 , respectively. The PASTIS_HVR was used to collect samples every 2-3m for benchtop flow cytometry analyses (Sect. 2.4). Complementary nutrient analyses were made at a lower vertical resolution $(10 \mathrm{~m})$. Nitrite and phosphate concentration profiles never overpassed the limits of quantification of the analyzers (data not shown). Twentyseven random seawater samples were collected and filtered 
FLR5
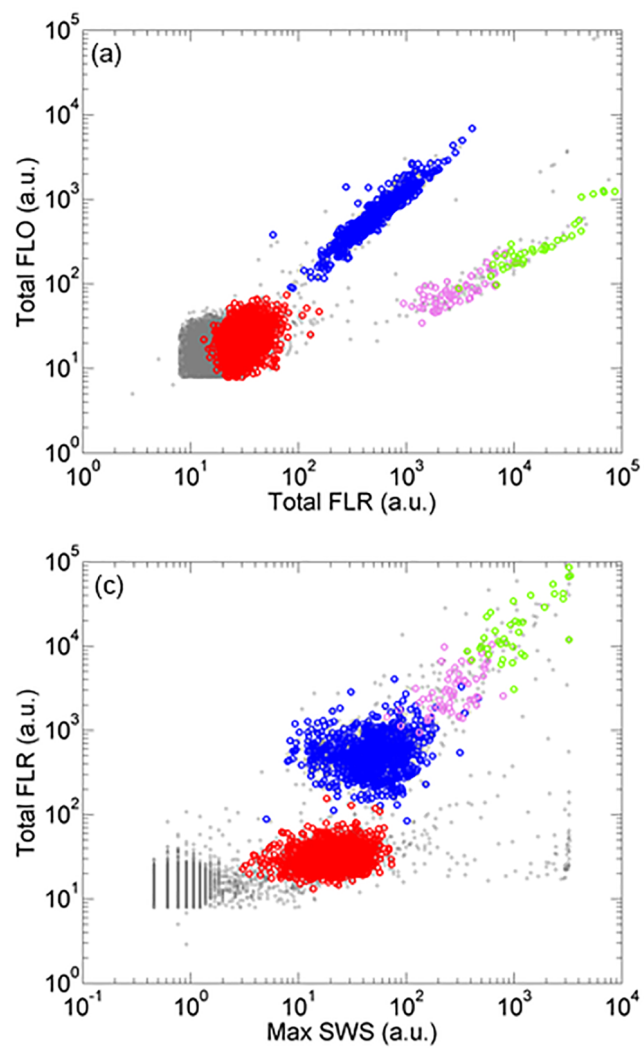

FLR30
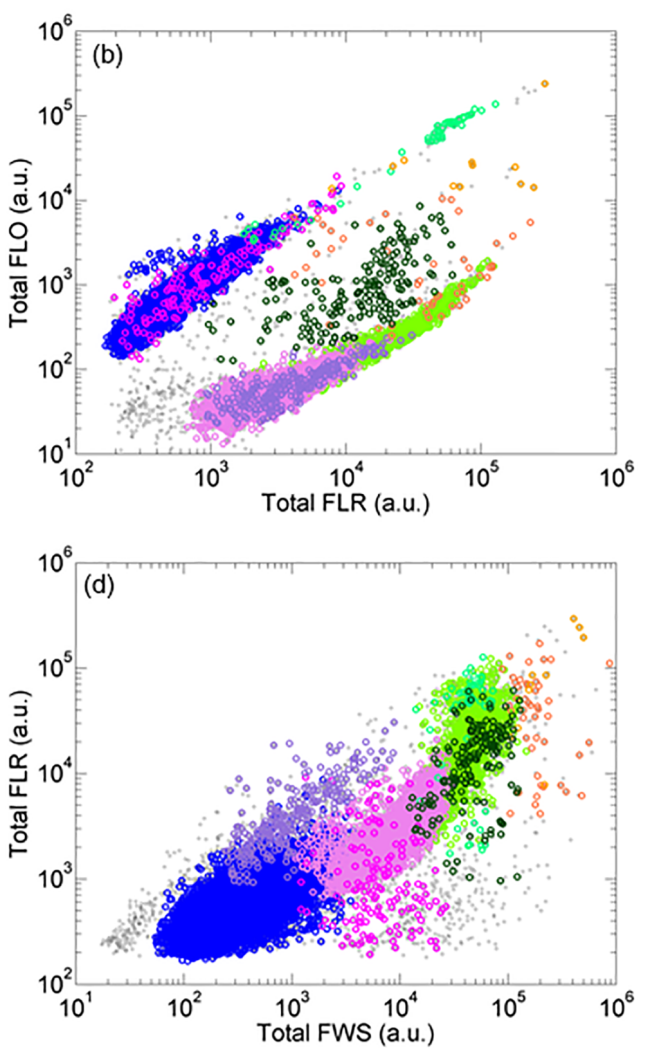

Figure 4. Cytograms of samples analyzed with the CytoSense automated flow cytometer and phytoplankton groups optically resolved represented by different colors. Cytograms $\mathrm{A}$ and $\mathrm{C}$ were obtained with a red fluorescence (FLR) trigger level of $5 \mathrm{mV}$ and cytograms $\mathrm{B}$ and D with a FLR trigger level of $30 \mathrm{mV}$. (a) Cytogram of total orange fluorescence (Total FLO (a.u.)) vs. Total FLR (a.u.). (b) Cytogram of Total FLO (a.u.) vs. Total FLR (a.u.). (c) Cytogram of Total FLR (a.u.)) vs. maximum sideward scatter (Max SWS (a.u.)). (d) Cytogram of Total FLR (a.u.) vs. total forward scatter (Total FWS (a.u.)). Prochlorococcus cells are in red, Synechococcus in blue, the main picoeukaryote group (PicoE) in pink, picoeukaryotes with high FLO (PicoHighFLO) in fuchsia, picoeukaryotes with high FLR (PicoHighFLR) in mauve, the main nanoeukaryote group (NanoE) in green, nanoeukaryotes with intermediate FLO (NanoFLO) in dark green, nanoeukaryotes with high FLO (NanoHighFLO) in cyan, microeukaryotes (MicroE) in dark orange and microeukaryotes with high FLO (MicroHighFLO) in orange.

to measure Chl $a$ concentration (Sect. 2.4) and to convert fluorescence signals into Chl $a$ values. A significant correlation between fluorescence and $\mathrm{Chl} a$ was obtained with a $R^{2}$ of 0.52 ( $p$ value $<0.05$ ). A cross-calibration in terms of fluorescence was performed between fluorometers of the CTD rosette and the CTD used for PASTIS_HVR to harmonize $\mathrm{Chl} a$ values (fluorescence ${ }_{\text {CTD PASTIS HVR }}=$ fluorescence ${ }_{\text {CTD_rosette }} \times 3.31, n=60, R^{2}=0.85$ ).

\subsection{Surface-specific growth rates and primary production estimates}

Phytoplankton growth rates were estimated by measuring independently with AFCM the net abundances combined with a size-structured population model described in Sosik et al. (2003) and adapted by Dugenne et al. (2014) and Dugenne (2017). Observed diel variations of single-cell bio- volumes within a specific cluster, retrieved from the power law relationship between cell size and FWS, were used as inputs for this size-structured population model. The absolute number of cells $(\boldsymbol{N})$ and proportions of cells $(\boldsymbol{w})$ were counted during $24 \mathrm{~h}$ to follow the transitions of cells in each size class $(v)$.

$\boldsymbol{N}=\left(\begin{array}{c}N_{1 \mid v=v_{1}} \\ \vdots \\ N_{i \mid v=v_{i}} \\ \vdots \\ N_{m \mid v=v_{\mathrm{m}}}\end{array}\right), \quad \boldsymbol{w}=\frac{\boldsymbol{N}}{\sum_{i=1}^{m} N_{i \mid v=v_{i}}}$

with $v_{1, \ldots, i, \ldots, m}$ denoting the size classes.

We identified the set of parameters that could optimally reproduce the diel variation of the population size distribution using only cell cycle transitions by inverse modeling. In the 
model, temporal transitions of cell proportions in size classes are assumed to result from either cellular growth, supported by photosynthetic carbon assimilation, or asexual division. The increase in cell size occurring during the interphase is dependent on the proportions of cells that will grow between $t$ and $t+\mathrm{d} t$, denoted $\gamma(t)$. This probability is expressed as an asymptotic function of incident irradiance (Eq. 2).

$\gamma(t)=\gamma_{\max } \cdot\left[1-\exp \left(-\frac{\text { Irradiance }}{\text { Irradiance }^{*}}\right)\right]$,

with Irradiance the instantaneous PAR, Irradiance* the scaling parameter, and $\gamma_{\max }$ the maximal proportion of cells growing between $t$ and $t+\mathrm{d} t$.

By contrast, the decrease in cell size occurring after the mitosis marks the production of two daughter cells whose size has been divided by a factor of 2 . Thus the decrease in cell size is dependent on the proportion of cells that will enter mitosis between $t$ and $t+\mathrm{d} t$, denoted $\delta(t)$, which ultimately controls the population net growth rates (Eq. 3).

$\mu(t)=\frac{1}{\mathrm{~d} t} \cdot \ln (1+\delta(t))$

Because natural populations show a clear temporal variation of the mitotic index $(\delta(t))$, the proportion of cells entering mitosis is expressed as a function of both time (Vaulot and Chisholm, 1987; André et al., 1999; Jacquet et al., 2001) and cell size (Marañón, 2015) (Eq. 4).

$\delta(t)=\delta_{\max } f\left(\mu_{v} \sigma_{v}^{2}\right) f\left(\mu_{t} \sigma_{t}^{2}\right)$

with $f$ the normal probability density, $v$ cell size, $\delta_{\max }$ the maximal proportion of cells entering mitosis, $\mu_{v}$ the mean of the size density distribution, $\sigma_{v}$ the SD of the size density distribution, $\mu_{t}$ the mean of the temporal density distribution, and $\sigma_{t}$ the SD of the temporal density distribution.

By analogy with a Markovian process, the initial distribution of the cell size, $N(0)$, is projected with a time step of $\mathrm{d} t=\frac{10}{60} \mathrm{~h}$, to construct the normalized size distribution, $\boldsymbol{w}(t)$, over a $24 \mathrm{~h}$ period (Eq. 5), with ^ standing for model predictions.

$\hat{\boldsymbol{N}}(t+\mathrm{d} t)=A(t) \hat{\boldsymbol{N}}(t)$ and $\hat{\boldsymbol{w}}(t+\mathrm{d} t)=\frac{A(t) \hat{\boldsymbol{N}}(t)}{\sum A(t) \hat{\boldsymbol{N}}(t)}$

The tridiagonal transition matrix, $\mathbf{A}(t)$, contains

1. the stasis probability, expressed as the proportions of cells that neither grew nor divided between $t$ and $t+\mathrm{d} t$,

2. the growth probability $(\gamma)$, expressed as the proportions of cells that grew between $t$ and $t+\mathrm{d} t$, and

3. the division probability $(\delta)$, expressed as the proportions of cells that entered division between $t$ and $t+\mathrm{d} t$.
The set of optimal parameters, $\boldsymbol{\theta}$ (Eq. 6), minimize the Gaussian error distribution between predictions $(\hat{\boldsymbol{w}})$ and observations $(\boldsymbol{w}), \sum(\boldsymbol{\theta})$ (Eq. 7). Their SDs are estimated by a Markov chain Monte Carlo approach that samples $\boldsymbol{\theta}$ from their prior density distribution, obtained after running 200 optimizations on bootstrapped residuals, to approximate the parameter posterior distribution using the normal likelihood.

$$
\begin{aligned}
& \boldsymbol{\theta}=\left\{\gamma_{\max }, \text { Irradiance }^{*}, \delta_{\max }, \mu_{v}, \sigma_{v}, \mu_{t}, \sigma_{t}\right\} \\
& =\operatorname{argmin}\left(\sum(\boldsymbol{\theta})\right) \\
& \sum(\boldsymbol{\theta})=\sum_{t=T 0}^{T 1 \text { day }} \sum_{i=1}^{m}(\boldsymbol{w}-\hat{\boldsymbol{w}}(\boldsymbol{\theta}))^{2}
\end{aligned}
$$

Ultimately, the equivalent of the temporal projection of proportions is conducted on the absolute diel size distribution $(N)$ with the optimal set of parameters to estimate population intrinsic growth rates $(\mu)$ on a $24 \mathrm{~h}$ period, from which the hourly logarithmic difference of observed abundances is subtracted to obtain the daily average population loss rates (l) (Eq. 8).

$$
\begin{aligned}
& \mu=\frac{1}{24 \cdot \frac{1}{\mathrm{~d} t}+1} \ln \left(\frac{\hat{N}\left(T_{1 \text { day }}\right)}{N\left(T_{0}\right)}\right) \text { and } \\
& \bar{l}=\int^{\mathrm{d} t=1 h} \mu(\mathrm{d} t)-\frac{1}{\mathrm{~d} t} \cdot \ln \left(\frac{N(t+\mathrm{d} t)}{N(t)}\right)
\end{aligned}
$$

The ratio between mean cell biovolume at dawn (min) and dusk (max) has been used for Synechococcus and other phytoplankton groups (Binder et al., 1996; Vaulot and Marie, 1999) as a minimum estimate of the daily growth rate. This simple approach assumes that cell growth and division are separated in time (synchronous population), whereas these processes occur simultaneously in a population (Waterbury et al., 1986; Binder and Chisholm, 1995; Jacquet et al., 2001). Since the model allows for any cell to grow, divide or be at equilibrium over the entire integration period (asynchronous populations), growth rates $\mu_{\text {size }}$ superior to the median size ratio $\mu_{\text {ratio }}=\ln \left(\bar{v}_{\max } / \bar{v}_{\text {min }}\right)$ (indicative of a synchronous population) are assumed to be well represented.

The apparent increase in carbon biomass, defined as the net primary production $\mathrm{NPP}_{\text {cell }}$ (Eq. $9, \mathrm{mg} \mathrm{Cm}^{-3} \mathrm{~d}^{-1}$ ), was calculated using a constant cell to carbon conversion factor $Q_{\mathrm{C} \text {, calc }}$ (Table 2).

$\mathrm{NPP}_{\text {cell }}=Q_{C} \delta(t) \hat{N}\left(T_{0}\right)=Q_{C}[\exp (\mu(t))-1] \hat{\boldsymbol{N}}\left(T_{0}\right)$

The biovolume to carbon $a v_{i}^{b}$ relationship (Table 2) was used to calculate the net primary production $\mathrm{NPP}_{\text {size }}$ (Eq. 10) as the differential of carbon distributions, as the scalar product 
of vectors $a v_{i}^{b}$ and $N$ over time:

$$
\begin{aligned}
\mathrm{NPP}_{\text {size }} & =\sum_{t \in R^{*}} \Delta\left(\left\langle C_{\text {size }}, \hat{N}(t+\mathrm{d} t)\right\rangle,\left\langle C_{\text {size }}, \hat{N}(t)\right\rangle\right) \\
& =\sum_{t=T_{0}}^{T_{0}+1 \text { day }-\mathrm{d} t} \sum_{i=1}^{m} a v_{i}^{b}\left(N_{i}(t+\mathrm{d} t)-N_{i}(t)\right) .
\end{aligned}
$$

These conversions allow approximation of the daily NPP using the approximation of the carbon content of the cells newly formed after mitotic division over $24 \mathrm{~h}\left(\mathrm{NPP}_{\text {cell }}\right)$, or directly assimilated by photosynthesis during the photoperiod $\left(\mathrm{NPP}_{\text {size }}\right)$. The estimations result from the apparent mitotic index optimally deduced from the diel dynamics of the normalized size distribution. They do not accommodate any cell removal process within the period of integration that could be caused by grazing or physical transport.

\section{Results}

\subsection{Description of the fine-scale structure}

Surface currents distributed by AVISO exhibited a cyclonic recirculation in the Ligurian subbasin (Fig. 1). Current velocities and directions measured by the ADCP were in general agreement with the altimetry-derived ones. The highest current velocities $\left(>0.3 \mathrm{~m} \mathrm{~s}^{-1}\right)$ were associated with the Northern Current. The main cyclonic circulation was divided into two parts: a small recirculation centered on $\left(8.75^{\circ} \mathrm{W}\right.$, $43.80^{\circ} \mathrm{N}$ ) and a second one in the southwest separated by a local minimum in current intensity, both observed in AVISO and ADCP data.

Between 30 October and 2 November, a strong northeasterly wind event (wind velocity of up to $70 \mathrm{~km} \mathrm{~h}^{-1}$ ) was recorded all over the area, associated with a SST drop of $\sim 1{ }^{\circ} \mathrm{C}$ in the Ligurian subbasin. Satellite SST images from 30 October to 6 November (Fig. 1) showed a patch of cold surface waters with values below $17.5^{\circ} \mathrm{C}$. The observation was confirmed by the ship surface TSG between 3 November and 6 November (mean SST of $16.3 \pm 0.3{ }^{\circ} \mathrm{C}$ and mean SSS below 38.20, Fig. 2, Table 1). The cold patch was surrounded by warmer surface waters with SST up to $19^{\circ} \mathrm{C}$, validated by in situ records from the TSG. Both satellite and in situ sampling described warm boundary waters characterized by SST higher than $17.0^{\circ} \mathrm{C}$. These warm boundary waters were divided into type 1 and type 2 (see Sect. 4.1). Type 2 warm boundary waters presented the highest SST (above $18^{\circ} \mathrm{C}$ ) and SSS values below 38.24. Type 1 warm boundary waters were defined as the surface waters characterized by SST values higher than $17.0^{\circ} \mathrm{C}$ and SSS above 38.23, apart from type 2 warm boundary waters. The lowest SST values were observed between 3 November and 5 November, and then the patch warmed up on 6 November. Remotely sensed SST was well correlated with the one recorded by the TSG along the ship track $\left(R^{2}=0.82, p\right.$ value $\left.<0.05\right)$, even if remote- sensing tended to underestimate SST. Temperature gradients observed from the TSG were well caught by satellite products.

Figure 3 depicts the temperature and salinity vertical section of a south-to-north MVP transect from 00:00 to 06:00 (local time) on 5 November. The thermocline was located between 20 and $30 \mathrm{~m}$ in depth in cold core area and between 30 and $40 \mathrm{~m}$ abroad. Temperatures above the thermocline were uniform in the cold core and warm boundary waters, while within the transition areas temperatures increased progressively from the thermocline to the surface (Fig. 3 and Fig. S1 in the Supplement). The deep water temperature, below the thermocline, ranged from 13.5 to $14.5^{\circ} \mathrm{C}$ and did not present any significant differences between the cold core and the warm boundaries. Sea surface salinity (SSS) was lower $(<38.20)$ in the cold core than in the warm boundaries $(>38.20)$ and salinity at $300 \mathrm{~m}$ in depth was higher than 38.50. A subsurface layer of low-salinity waters $(<38.10)$ spread off below the thermocline with a 40 to $80 \mathrm{~m}$ thickness. This subsurface layer was observed up to the surface in the center of the cold core, whereas in warm boundaries saltier (> 35.20) surface waters overlaid it.

Remotely sensed Chl $a$ concentration estimates ranged between 0.10 and $0.30 \mu \mathrm{g} \mathrm{dm}^{-3}$ during the campaign (Fig. 1). Unfortunately cloud cover masked the remote-sensing Chl $a$ from 3 November to 5 November. The study area (black square in Fig. 1) was considered case 1 waters (Morel et al., 2006). On 30 October, remotely sensed surface Chl $a$ concentrations ranged from 0.10 to $0.20 \mu \mathrm{g} \mathrm{dm}^{-3}$. On 2 November, concentrations higher than $0.30 \mu \mathrm{g} \mathrm{dm}^{-3}$ were observed in the center of the cold patch and decreased below $0.20 \mu \mathrm{g} \mathrm{dm}^{-3}$ on 6 November. Mean satellite Chl $a$ estimates recorded and averaged from 2 November to 6 November were significantly correlated with $\mathrm{Chl} a$ derived from the ship fluorometer during the campaign $\left(R^{2}=0.47, p\right.$ value $<$ 0.05). The highest Chl $a$ concentrations measured from TSG fluorescence were recorded in the center of the cold patch, with Chl $a$ concentrations up to $0.40 \mu \mathrm{g} \mathrm{dm}^{-3}$ and mean Chl $a$ of $0.17 \pm 0.04 \mu \mathrm{g} \mathrm{dm}^{-3}$ (Table 1), while warm boundaries presented lower $\mathrm{Chl} a$ concentrations $\left(<0.15 \mu \mathrm{g} \mathrm{dm}^{-3}\right)$.

Surface nutrient variability was investigated from the 177 discrete samplings performed every 20 min (Table 1). Surface nitrate, nitrite and phosphate concentrations were below

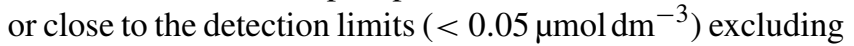
any spatial variability observation. Only silicate concentration presented detectable variability in its distribution, with mean values of $1.31 \pm 0.05 \mu \mathrm{mol} \mathrm{dm}{ }^{-3}$ in the cold core and $1.19 \pm 0.06 \mu \mathrm{mol} \mathrm{dm}{ }^{-3}$ in the warm boundary surface water (Table 1).

Deep Chl $a$ maxima (DCM) were observed in the vicinity of 30 and $45 \mathrm{~m}$ in depth for the cold core and warm boundary stations, respectively (Fig. S1). DCM occurred approximately $10 \mathrm{~m}$ below the thermocline. DCM Chl $a$ concentration values were comprised between 0.30 and $0.40 \mu \mathrm{g} \mathrm{dm}^{-3}$ in the cold core and between 0.20 and $0.30 \mu \mathrm{g} \mathrm{dm}^{-3}$ in 
Table 1. Mean and SD values of SST, SSS, density, Chl $a$, nitrate, nitrite, phosphate and silicate in the cold core and warm boundaries 1 and 2 during the OSCAHR campaign. Prochlorococcus, Synechococcus, PicoEukaryote (PicoE, PicoHighFLR, PicoHighFLO), NanoEukaryote (NanoE, NanoFLO, NanoHighFLO) and MicroEukaryote (MicroE, MicroHighFLO) abundances are expressed in number of cells (N) per $\mathrm{cm}^{-3}$, and the mean red fluorescences of Prochlorococcus, Synechococcus, PicoE and NanoE are expressed in arbitrary units (a.u.) per cell for each hydrographical province.

\begin{tabular}{|c|c|c|c|c|c|}
\hline & & & Cold core & Warm boundary 1 & Warm boundary 2 \\
\hline & Number of samplings & & 76 & 78 & 23 \\
\hline & $\operatorname{SST}\left({ }^{\circ} \mathrm{C}\right)$ & & $16.3 \pm 0.3$ & $17.9 \pm 0.5$ & $18.8 \pm 0.1$ \\
\hline & SSS & & $38.19 \pm 0.02$ & $38.26 \pm 0.02$ & $38.22 \pm 0.01$ \\
\hline & Density & & $1028.1 \pm 0.1$ & $1027.8 \pm 0.1$ & $1027.6 \pm 0.0$ \\
\hline & Chl $a\left(\mu \mathrm{g} \mathrm{dm}^{-3}\right)$ & & $0.17 \pm 0.04$ & $0.11 \pm 0.03$ & $0.12 \pm 0.01$ \\
\hline & $\mathrm{NO}_{3}^{-}\left(\mu \mathrm{mol} \mathrm{kg}{ }^{-1}\right)$ & & $<0.05$ & $<0.05$ & $<0.05$ \\
\hline & $\mathrm{NO}_{2}^{-}\left(\mu \mathrm{molkg} \mathrm{kg}^{-1}\right)$ & & $<0.05$ & $<0.05$ & $<0.05$ \\
\hline & $\mathrm{PO}_{4}^{3-}\left(\mu \mathrm{mol} \mathrm{kg}{ }^{-1}\right)$ & & $<0.05$ & $<0.05$ & $<0.05$ \\
\hline & $\mathrm{Si}(\mathrm{OH})_{4}(\mu \mathrm{mol} \mathrm{kg}-1)$ & & $1.31 \pm 0.05$ & $1.20 \pm 0.05$ & $1.13 \pm 0.04$ \\
\hline \multirow[t]{2}{*}{ Prochlorococcus } & Abundance $\left(\mathrm{Ncm}^{-3}\right)$ & $\times 10^{4}$ & $3.5 \pm 0.8$ & $2.0 \pm 0.6$ & $2.4 \pm 0.2$ \\
\hline & Mean red fluorescence (a.u. cell ${ }^{-1}$ ) & $\times 10^{1}$ & $4.3 \pm 0.8$ & $3.7 \pm 0.6$ & $4.8 \pm 0.5$ \\
\hline \multirow[t]{2}{*}{ Synechococcus } & Abundance $\left(\mathrm{Ncm}^{-3}\right)$ & $\times 10^{4}$ & $1.8 \pm 0.3$ & $2.5 \pm 0.3$ & $3.1 \pm 0.2$ \\
\hline & Mean red fluorescence (a.u. cell ${ }^{-1}$ ) & $\times 10^{2}$ & $5.0 \pm 0.4$ & $4.2 \pm 0.6$ & $5.9 \pm 1.0$ \\
\hline \multirow[t]{2}{*}{ PicoEukaryotes } & Abundance $\left(\mathrm{N} \mathrm{cm}^{-3}\right)$ & $\times 10^{3}$ & $1.5 \pm 0.2$ & $1.1 \pm 0.1$ & $1.2 \pm 0.1$ \\
\hline & Mean red fluorescence (a.u. cell ${ }^{-1}$ ) & $\times 10^{3}$ & $3.5 \pm 0.3$ & $3.3 \pm 0.5$ & $4.5 \pm 0.6$ \\
\hline \multirow[t]{2}{*}{ NanoEukaryotes } & Abundance $\left(\mathrm{N} \mathrm{cm}^{-3}\right)$ & $\times 10^{2}$ & $8.9 \pm 0.8$ & $7.8 \pm 1.3$ & $8.1 \pm 0.6$ \\
\hline & Mean red fluorescence (a.u. cell ${ }^{-1}$ ) & $\times 10^{4}$ & $2.0 \pm 0.2$ & $1.8 \pm 0.2$ & $2.0 \pm 0.2$ \\
\hline MicroEukaryotes & Abundance $\left(\mathrm{N} \mathrm{cm}^{-3}\right)$ & $\times 10^{1}$ & $2.8 \pm 0.4$ & $2.7 \pm 0.3$ & $2.5 \pm 0.3$ \\
\hline
\end{tabular}

the warm boundary waters. The euphotic zone $\left(Z_{\text {eu }}\right)$ spread down around $70 \mathrm{~m}$ all over the study area (Figs. S1 and S2).

\subsection{Phytoplankton group definition}

Up to 10 phytoplankton groups were resolved by AFCM on the basis of their light scatter (namely forward scatter FWS and sideward scatter SWS) and fluorescence (red FLR and orange FLO fluorescence ranges) properties over the 177 validated samples collected using two-dimensional projections (cytograms, Fig. 4). Due to their small sizes and their limited photosynthetic pigment contents, Prochlorococcus were resolved close to the limit of the AFCM detection capacity means of the maximum SWS and FLR pulse shape curves. Cells assigned to the Synechococcus group were unambiguously resolved thanks to their higher FLO intensity compared to their FLR intensity (Fig. 4a and b) induced by the presence of phycoerythrin pigments. According to a $\log -\log$ linear regression relying on FWS to the equivalent spherical diameter (ESD), Prochlorococcus and Synechococcus exhibited a mean ESD of $0.5 \pm 0.1 \mu \mathrm{m}$ $\left(0.07 \pm 0.03 \mu \mathrm{m}^{3}\right)$ and $0.9 \pm 0.2 \mu \mathrm{m}\left(0.46 \pm 0.38 \mu \mathrm{m}^{3}\right)$, respectively (Table 2). Prochlorococcus and Synechococcus continuous surface counts were compared to conventional flow cytometry analyses performed with the FACSCalibur flow cytometer on discrete samples collected at fixed stations at the first two sampling depths near the surface (Fig. S3). The two counting methods did not show significant differences ( $t$ test, $p$ value $<0.001$, which validates the observations obtained with the automated CytoSense. A post-campaign validation against conventional flow cytometers showed a good fit of data (Student test $p>0.4$, Table S1 in the Supplement).

With a higher trigger level (FLR30) it was possible to resolve and count larger cells in $5 \mathrm{~cm}^{3}$, from picoeukaryotes to microeukaryotes (Fig. 4c and d). Three groups of picoeukaryotes were resolved on the basis of their optical properties. The main picoeukaryote group (PicoE) exhibited higher FLR and FWS and lower FLO intensities than Synechococcus, with an ESD of $2.6 \pm 0.5 \mu \mathrm{m}\left(10.5 \pm 5.5 \mu \mathrm{m}^{3}\right)$ (Table 2). One picoeukaryote group with high FLO (PicoHighFLO) and another with high FLR (PicoHighFLR) were also identified during the campaign (Fig. $4 \mathrm{c}$ and d). Three distinct nanoeukaryote groups were defined according to their red and orange fluorescence properties. The main nanoeukaryote group (NanoE) had a FLR/FLO ratio close to the PicoE ratio (Fig. 4c), with an ESD of $4.1 \pm 0.5 \mu \mathrm{m}\left(37.0 \pm 14.7 \mu \mathrm{m}^{3}\right)$ (Table 2). Nanoeukaryote cells, which emitted orange fluorescence with higher intensities than red fluorescence, were divided into two additional groups: NanoFLO and NanoHighFLO, respectively. The distinction between nano- and microeukaryotes was made by combining FWS and the pictures collected by the image-in-flow device of CytoSense. During the campaign, taxonomic identification based on pictures taken by the image-in-flow device was impossible due the lack of a sufficient number of phytoplanktonic cells with sizes above $20-30 \mu \mathrm{m}$ (the size from which a taxanomic iden- 

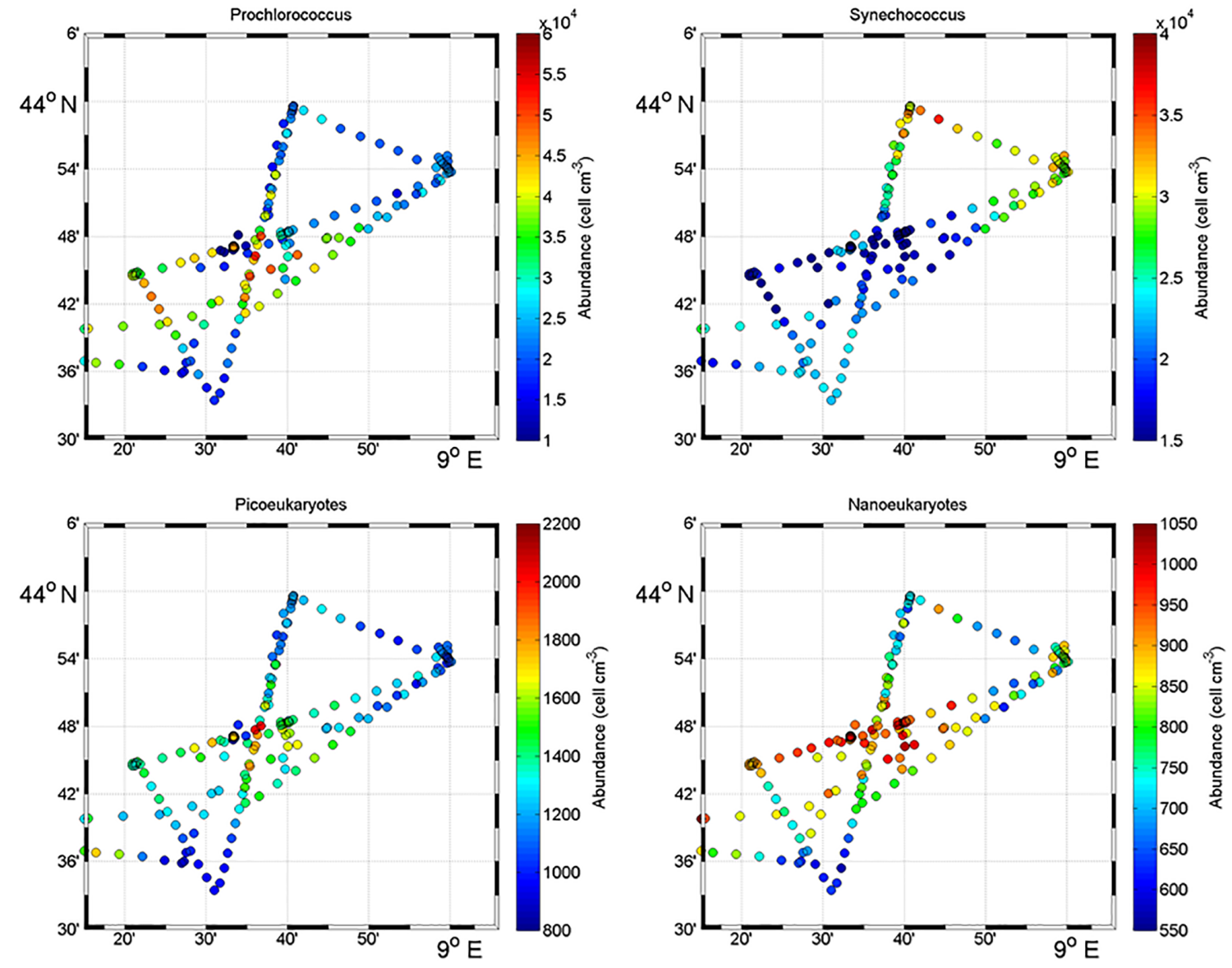

Figure 5. Surface distribution of Prochlorococcus, Synechococcus, picoeukaryote (PicoE + PicoHighFLR + PicoHighFLO) and nanoeukaryote $(\mathrm{NanoE}+\mathrm{NanoFLO}+\mathrm{NanoHighFLO})$ abundances $\left(\right.$ in cell $\left.\mathrm{cm}^{-3}\right)$.

tification can be performed). Two types of microeukaryotes were distinguished: microeukaryotes (MicroE) with a size ranging between 10 and $20 \mu \mathrm{m}$ and microeukaryotes with high FLO (MicroHighFLO) with a size above $20 \mu \mathrm{m}$. The relatively small size of most of the MicroE limited their identification. The MicroE was not properly a microphytoplankton group according to the official size classification (20$200 \mu \mathrm{m}$ ), but it was distinct from the three nanoeukaryote groups $(\mathrm{ESD}<5 \mu \mathrm{m})$.

\subsection{Phytoplankton group distribution}

Figure 5 shows the surface abundance of Prochlorococcus, Synechococcus, picoeukaryote and nanoeukaryote groups over the study area. Picoeukaryote and nanoeukaryote abundances were computed as the sum of the three picoeukaryote (PicoE, PicoHighFLO and PicoHighFLR) and nanoeukaryote (NanoE, NanoFLO and NanoHighFLO) groups, respectively, in order to simplify the representation of the phytoplankton group distribution. Prochlorococcus abundances varied between 8800 and 51500 cells cm$^{-3}$ (Fig. 5a), with higher abundances in the center of the structure $\left(>30000\right.$ cells $\mathrm{cm}^{-3}$ ) corresponding to the cold core (Fig. 2a). In warm boundaries, Prochlorococcus abundances were below 30000 cells cm${ }^{-3}$, with on average $20000 \pm 6000$ cells $\mathrm{cm}^{-3}$ (Table 1). The Synechococcus population ranged from 13500 to 35900 cells cm$^{-3}$ (Fig. 5b). In the patch of cold waters, Synechococcus mean abundance was $18000 \pm 3000 \mathrm{cells} \mathrm{cm}^{-3}$, and in the surrounding warm waters a mean abundance of $25000 \pm 3000$ cells cm$^{-3}$ was observed. Picoeukaryote abundances varied between 875 and 2040 cells $\mathrm{cm}^{-3}$ and nanoeukaryote abundances ranged from 567 to $1175 \mathrm{cells} \mathrm{cm}^{-3}$. Picoeukaryote and nanoeukaryote populations presented a similar surface distribution pattern to the Prochlorococcus one, with higher abundances in the cold core than in warm boundaries. In the cold patch, mean abundances of $1200 \pm 200 \mathrm{cells} \mathrm{cm}^{-3}$ and $890 \pm 90$ cells cm$^{-3}$ were observed for picoeukaryotes and nanoeukaryotes, respectively. Warm boundary surface waters hosted picoeukaryote and nanoeukaryote average populations of $900 \pm 100$ cells cm $\mathrm{cm}^{-3}$ and $780 \pm 130$ cells cm$^{-3}$, respectively (Table 1). PicoHighFLO and NanoFLO did not exhibit a clear pattern between cold core and warm boundaries (data not shown), with abundances varying between 


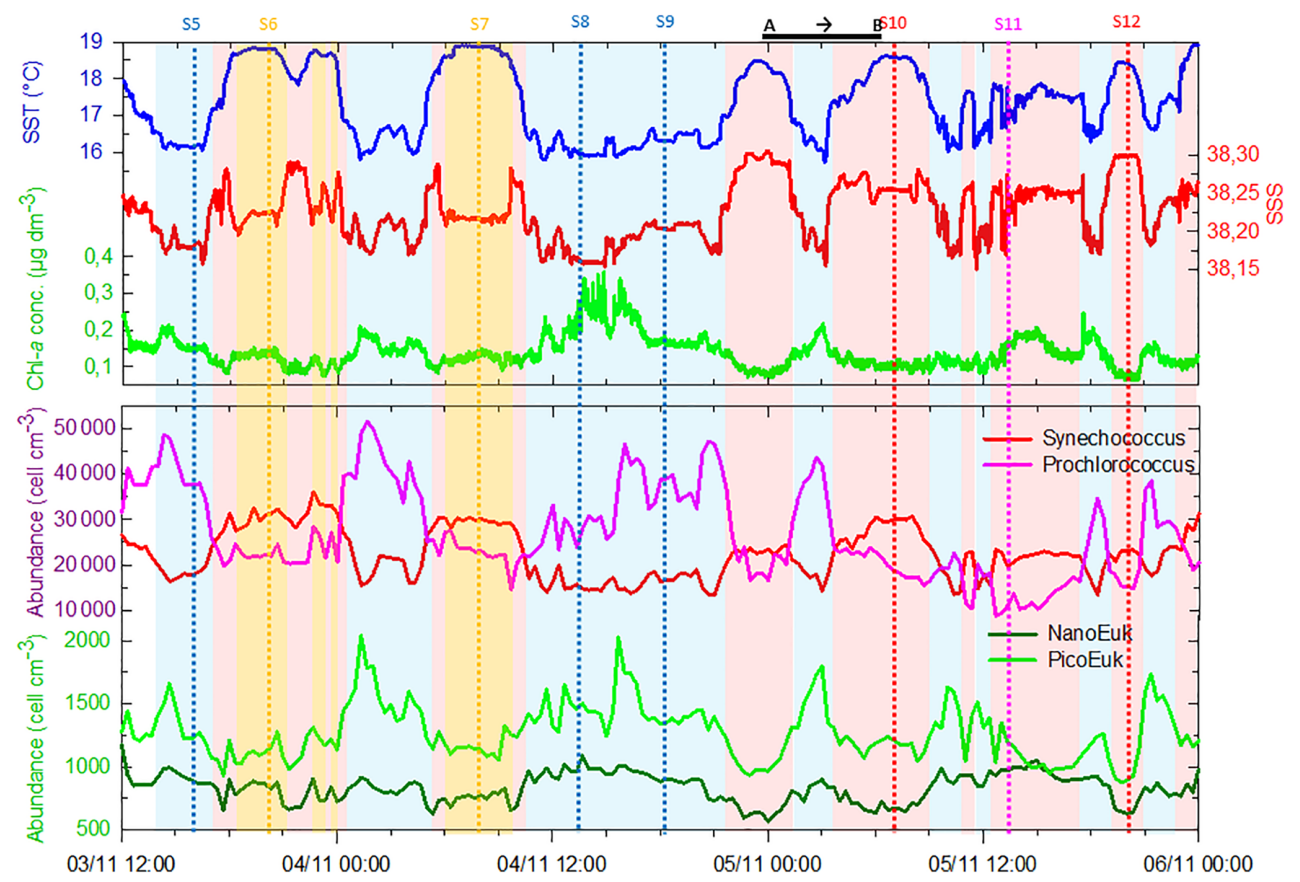

Figure 6. Continuous measurements of SST (in ${ }^{\circ} \mathrm{C}$ ), SSS and $\mathrm{Chl} a$ concentrations (in $\mu \mathrm{g} \mathrm{dm}^{-3}$ ) of surface waters during the OSCAHR campaign from 3 November 12:00 to 6 November 00:00 (local time), with associated surface abundances (in cells $\mathrm{cm}^{-3}$ ) of Prochlorococcus, Synechococcus, picoeukaryotes (PicoE + PicoHighFLO + PicoHighFLR) and nanoeukaryotes (NanoE + NanoFLO + NanoHighFLO). The background color code corresponds to cold core surface waters in blue, warm boundary waters of type 1 in red and warm boundary waters of type 2 in orange (more details in Sect. 4.2). Vertical dashed lines represent sampling times of the eight fixed stations (STA5 to STA12) performed during the campaign and colors correspond to the type of surface waters in which stations were performed. The purple color for STA11 shows that STA11 was performed in transition surface waters between cold core and warm boundary 1 surface waters. Start and end of the MVP transect presented in Fig. 3 are represented by a horizontal black line.

50 and 150 cells $\mathrm{cm}^{-3}$. PicoHighFLR abundance was below 100 cells $\mathrm{cm}^{-3}$ during the entire campaign, except in the vicinity of Station 8 (Fig. 2), where it reached up to 400 cells $\mathrm{cm}^{-3}$ and where the highest $\mathrm{Chl} a$ values were recorded (Fig. 6). NanoHighFLO showed the same behavior as PicoHighFLR, with abundances below 50 cells $\mathrm{cm}^{-3}$ during the campaign and a peak of up to 200 cells $\mathrm{cm}^{-3}$ in the same area. Variations of microeukaryotes (between 20 and 30 cells $\mathrm{cm}^{-3}$ and below 5 cells $\mathrm{cm}^{-3}$ for MicroE and MicroHighFLO, respectively) are not shown considering their low and relatively homogeneous abundances during the campaign and throughout the different type of surface waters (Table 1). However, MicroHighFLO abundances were exceptionally high in the vicinity of Station 8 (up to 20 cell $\mathrm{cm}^{-3}$ ).

Figure 6 illustrates the temporal surface variability of Prochlorococcus, Synechococcus, picoeukaryote and nanoeukaryote abundances together with temporal variations of SST, SSS and Chl a concentration. Prochlorococcus and Synechococcus abundances exhibited an opposite distribution throughout the cold and warm surface waters, with the dominance of Prochlorococcus in cold core waters and of Synechococcus in warm boundary waters. These shifts fitted perfectly with the short-term transitions observed from the
SST all along the cruise. Picoeukaryote maximal abundances (around 2000 cells $\mathrm{cm}^{-3}$ ) were observed simultaneously with the highest values of $\mathrm{Chl} a$ concentrations in cold waters, and lower abundances were found in warm and $\mathrm{Chl} a$-poor surface waters. The nanoeukaryote population followed a similar trend.

\subsection{Contribution to total fluorescence and carbon biomass}

The relative contributions to red fluorescence $\mathrm{FLR}_{i}$ by Prochlorococcus, Synechococcus, picoeukaryotes (PicoE, PicoHighFLO, PicoHighFLR), nanoeukaryotes (NanoE, NanoFLO, NanoHighFLO), and microphytoplankton (MicroE, MicroHighFLO) groups were obtained by multiplying their mean cell's red fluorescence intensity $\left(\mathrm{FLR}_{\mathrm{m}}\right)$ recorded by AFCM by their respective abundances according to $\mathrm{FLR}_{i}=\left(\mathrm{FLR}_{\mathrm{m}, i} \cdot\right.$ Abundance $\left._{i}\right)$. The integrative $\mathrm{FLR}_{\text {Total }}$ signal was calculated as $\mathrm{FLR}_{\text {Total }}=\sum_{i} \mathrm{FLR}_{i}$. The ratios $\mathrm{FLR}_{i} / \mathrm{FLR}_{\text {Total }}$ give an estimate of the contribution of each phytoplankton group to the bulk fluorescence signal. A significant correlation $\left(R^{2}=0.80, n=144\right)$ was established between computed FLR Total $_{\text {and }} \mathrm{Chl} a$ concentrations de- 
Table 2. Mean and SD of forward scatter (FWS), equivalent spherical diameter (ESD) and biovolume of Prochlorococcus, Synechococcus, PicoEukaryotes (PicoE) and NanoEukaryotes (NanoE) during the OSCAHR campaign. ESD was computed according to the power law relationship $\left(\log (\right.$ Size $\left.)=0.309 \cdot \log (\mathrm{FWS})-1.853, n=17, r^{2}=0.94\right)$ obtained with silica beads of known diameter. Biovolumes were calculated considering that the cells were spherical. Biovolumes were converted into a mean carbon cellular quota $\left(Q_{\mathrm{C} \text {, calc }}\right)$ according to the $Q_{\mathrm{C} \text {, calc }}=a \cdot$ Biovolume $^{b}$ relationship using conversion factors $a$ and $b$ reported by (1) Menden-Deuer and Lessard (2000). Carbon cellular quotas $\left(Q_{\mathrm{C}}\right.$, lit, lit for literature) from (2) Campbell et al. (1994) and (3) Shalapyonok et al. (2001) were reported for comparison.

\begin{tabular}{lrrrr}
\hline & Prochlorococcus & Synechococcus & PicoEukaryotes & NanoEukaryotes \\
\hline FWS $($ a.u. cell & -1 \\
ESD $(\mu \mathrm{m})$ & $48 \pm 21$ & $357 \pm 335$ & $1.0 \times 10^{4} \pm 0.6 \times 10^{4}$ & $4.0 \times 10^{4} \pm 1.7 \times 10^{4}$ \\
Biovolume $\left(\mu \mathrm{m}^{3}\right.$ cell $\left.^{-1}\right)$ & $0.5 \pm 0.1$ & $0.9 \pm 0.2$ & $2.6 \pm 0.5$ & $4.1 \pm 0.5$ \\
Conversion coefficients $(a, b)$ & $0.07 \pm 0.03$ & $0.46 \pm 0.38$ & $10.5 \pm 5.5$ & $37.0 \pm 14.7$ \\
$Q_{\mathrm{C}, \text { calc }}\left(\mathrm{fg} \mathrm{Ccell}^{-1}\right)$ & $(0.26,0.86)^{1}$ & $(0.26,0.86)^{1}$ & $(0.26,0.86)^{1}$ & $(0.433,0.863)^{1}$ \\
$Q_{\mathrm{C}, \text { lit }}\left(\mathrm{fg} \mathrm{C}\right.$ cell $\left.^{-1}\right)$ & 25 & 109 & 1880 & 9000 \\
\hline
\end{tabular}

rived from continuous surface fluorescence measurements (Fig. 7b), by excluding the orange dots which corresponded to data acquired in type 2 warm boundary waters characterized by abnormally high FLR recorded by the AFCM compared to the TSG fluorometer (see Sect. 4.3.4). When one considers only the relative contributions of each group in the cold core (blue) and warm boundary of type 1 (red), Prochlorococcus contributed $4.4 \pm 1.7 \%$ and $2.5 \pm 1.1 \%$ of FLR $_{\text {Total }}$, and Synechococcus FLR accounted for $24.5 \pm 4.2 \%$ and $33.3 \pm 4.4 \%$ of $F_{L R}$ Total, respectively. Picoeukaryotes contributed $14.4 \pm 1.9 \%$ and $11.7 \pm 1.9 \%$ of FLR Total $_{\text {and }}$ nanoeukaryote FLR accounted for $50.6 \pm 4.5 \%$ and $46.5 \pm$

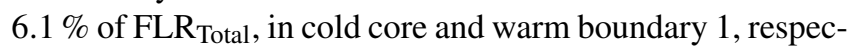
tively. Microphytoplankton contribution was around $6 \%$ in both hydrographical provinces, with a peak of contribution (>10\%) observed in the vicinity of the highest $\mathrm{Chl} a$ values recorded near Station 8 (Fig. 7a).

Similar calculations of $\mathrm{C}$ biomass were performed according to the cellular $\mathrm{C}$ quota $\left(Q_{\mathrm{C} \text {, calc }}\right.$, Table 2$)$ defined for Prochlorococcus, Synechococcus, picoeukaryote and nanoeukaryote groups and their abundances. The $\mathrm{C}$ individual cellular quota $\left(Q_{\mathrm{C} \text {, calc }}\right)$ has been derived from the average cell size according to the allometric regression formula $Q_{\mathrm{C} \text {, calc }}=a \cdot$ Biovolume $^{b}$ (Menden-Deuer and Lessard, 2000). This yielded average $\mathrm{C}$ biomasses of $25 \mathrm{fg} \mathrm{C}^{-1} \mathrm{Cll}^{-1}$ for Prochlorococcus cells, $109 \mathrm{fg} \mathrm{Cell}^{-1}$ for Synechococcus cells, $1880 \mathrm{fg} \mathrm{Cell}^{-1}$ for picoeukaryote cells and $9000 \mathrm{fg} \mathrm{C} \mathrm{cell}^{-1}$ for nanoeukaryote cells (Table 2). No cellular $\mathrm{C}$ quota was assigned to the microphytoplankton cluster regarding the large size range observed (from $10 \mu \mathrm{m}$ up to $80 \mu \mathrm{m})$. In cold core waters, the relative contributions of Prochlorococcus, Synechococcus, picoeukaryote and nanoeukaryote groups were $6 \pm 1 \%, 14 \pm 2 \%, 20 \pm 2 \%$ and $60 \pm 3 \%$, respectively. In warm boundary waters, these relative contributions accounted for $4 \pm 1 \%, 22 \pm 3 \%, 17 \pm 2 \%$ and $57 \pm 5 \%$. FLR and C biomass followed the same dynamics between both hydrographical provinces.

\subsection{Fine-scale vertical variability}

The fine-scale vertical variability of temperature, salinity and $\mathrm{Chl} a$ concentration was investigated in the first $35 \mathrm{~m}$ of the water column during several discrete station stops together with phytoplankton abundances sampled every 2$3 \mathrm{~m}$ (Fig. 8) with the dedicated PASTIS_HVR pump system. Fixed stations were grouped into cold core (stations $5,8,9$, and 11) and warm boundary stations (stations 6, 7 , and 10) depending on their surface water temperatures (Figs. 2 and 6). Profiles performed at warm boundary stations over the first $35 \mathrm{~m}$ were mostly homogeneous. Temperatures ranged between 18 and $19^{\circ} \mathrm{C}$, salinity values were higher than 38.20 and $\mathrm{Chl} a$ concentrations were lower than $0.10 \mu \mathrm{g} \mathrm{dm}^{-3}$. Nitrate concentrations remained lower than $0.05 \mu \mathrm{mol} \mathrm{dm}^{-3}$ and silicate concentrations varied between 1.15 and $1.20 \mu \mathrm{mol} \mathrm{dm}^{-3}$. Picophytoplankton abundances exhibited the same uniform vertical patterns. Prochlorococcus abundances remained below 30000 cells cm $\mathrm{cm}^{-3}$, the Synechococcus population counted over 30000 cells $\mathrm{cm}^{-3}$ and picoeukaryotes varied between 800 and 1200 cells cm$^{-3}$. As previously described in Sect. 3.1, the thermocline was located between 30 and $40 \mathrm{~m}$, below the PASTIS_HVR sampling depth. Profiles performed in cold surface water areas showed a decrease in temperatures from 15 to $30 \mathrm{~m}$ in depth occurring together with an increase in Chl $a$ concentrations of up to $0.60 \mu \mathrm{g} \mathrm{dm}^{-3}$. Higher values of nitrate and silicate were recorded concomitantly with the temperature drawdown and Chl $a$ increase. Prochlorococcus and picoeukaryote populations became more abundant in depth and reached concentrations of up to 97000 cells cm$^{-3}$ and 5200 cells cm$^{-3}$, while Synechococcus abundance tended to decrease, together with the temperatures, below 4000 cells $\mathrm{cm}^{-3}$. Station 11 (Fig. 2) was considered a cold core station regarding its vertical profile (Fig. 7) even though the surface was relatively warm (Fig. 6), with Synechococcus more abundant than Prochlorococcus. Station 11 was positioned in a transition area between the warm boundaries and 

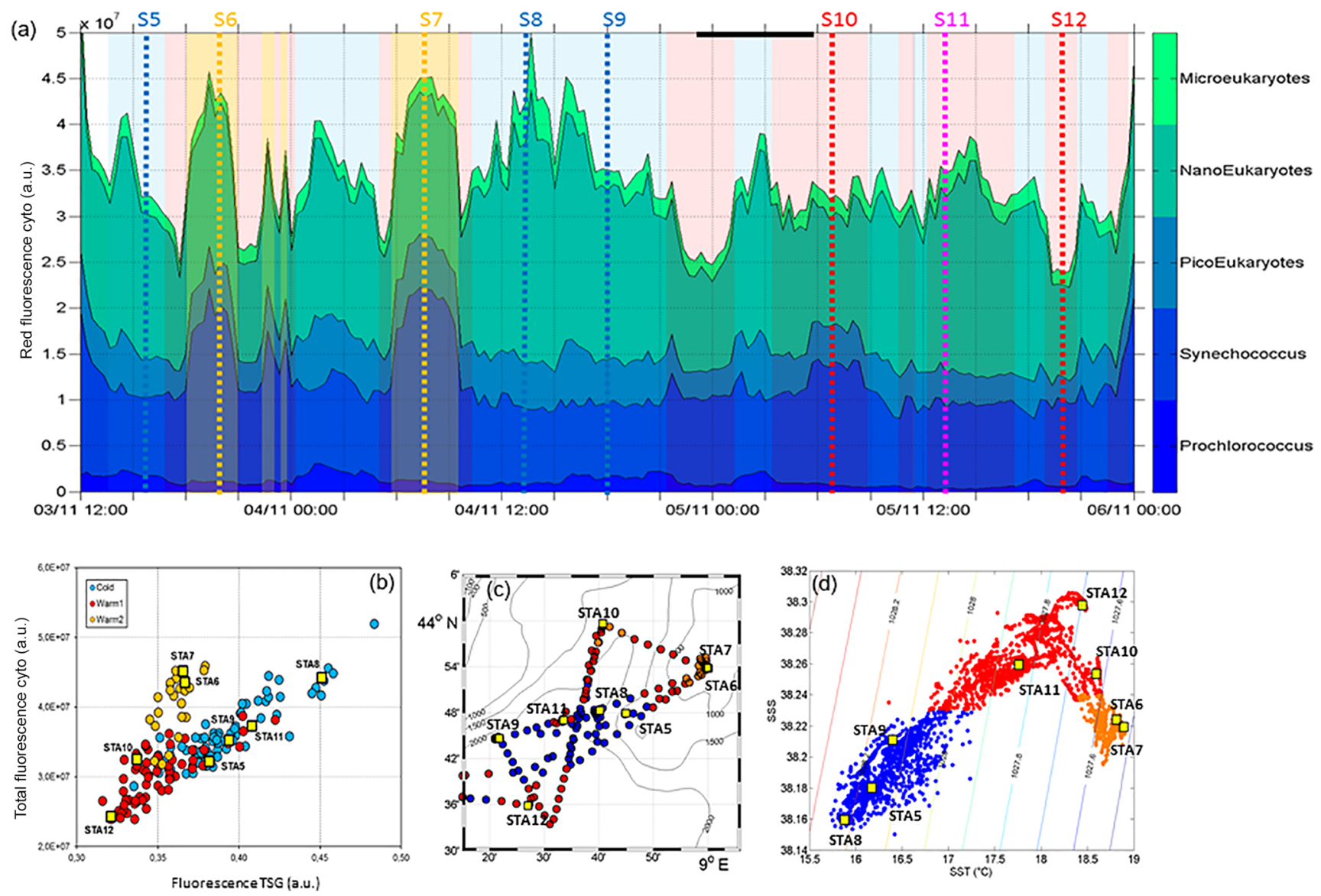

Figure 7. (a) Relative contribution $\mathrm{FLR}_{i}=\left(\mathrm{FLR}_{m, i} \cdot\right.$ Abundance $\left._{i}\right)$ of Prochlorococcus, Synechococcus, picoeukaryotes (PicoE + PicoHighFLR + PicoHighFLO), nanoeukaryotes (NanoE + NanoFLO + NanoHighFLO) and microeukaryotes (MicroE + MicroHighFLO) to the integrated red fluorescence signal $\left(\mathrm{FLR}_{\text {Total }}=\sum_{i}\left(\mathrm{FLR}_{m, i} \cdot\right.\right.$ Abundance $\left._{i}\right)$ ) from 3 November 12:00 to 6 November 00:00. Vertical dashed lines represent sampling times of the eight fixed stations (STA5 to STA12) performed during the campaign and colors correspond to the type of surface waters in which stations were performed. (b) Fluorescence recorded with the FLRTotal (in a.u.) vs. TSG (in a.u.) recorded by the automated flow cytometer. Blue, red and orange dots correspond to sampling performed in cold core, warm boundary 1 and boundary 2 surface waters. (c) Sampling positions of automated flow cytometry surface measurements. Blue, red and orange dots correspond to sampling performed in cold core, warm boundary 1 and boundary 2 surface waters. (d) SSS vs. SST (in ${ }^{\circ} \mathrm{C}$ ) plot from continuous TSG measurements with corresponding density isolines. The distinction between cold core and warm boundary 1 and 2 surface waters throughout the paper was made according to this plot.

the cold core. In the cold core stations, vertical profiles exhibited heterogeneous patterns, because of a shallower thermocline (Fig. S1), impacting physical and biogeochemical fine-scale variability. These results corroborated the observations obtained from the MVP profiles (Fig. 3), suggesting a shallowing of the thermocline and the associated surface mixed layer limit in the cold core.

\subsection{Growth rates and primary production estimates}

Prochlorococcus and Synechococcus size distributions were retrieved over $24 \mathrm{~h}$ according to the power law function relying on FWS to biovolume. On 5 November, the different types of waters were crossed several times by the ship. In order to select FWS measurements performed in the warm boundary waters this day, the individual cell FWS measurements were subsampled on an hourly scale from the $20 \mathrm{~min}$ AFCM measurements. In this way we were able to follow the diurnal variability of population size distribution only in the warm boundary waters (Fig. 6). Figures $9 a$ and $b$ show the hourly cell biovolume variations over $24 \mathrm{~h}$ for Prochlorococcus and Synechococcus, respectively. A diurnal cycle was described for both populations, with minimal and maximal biovolumes observed at 06:00 and at 18:00 (local time), respectively. Prochlorococcus biovolume varied from $0.04 \mu \mathrm{m}^{3}(\mathrm{ESD}=0.42 \mu \mathrm{m})$ to $0.12 \mu \mathrm{m}^{3}(\mathrm{ESD}=0.61 \mu \mathrm{m})$ between dawn and dusk. At the end of the dark period (06:00), Synechocococcus biovolume decreased down to $0.20 \mu \mathrm{m}^{3}$ $(\mathrm{ESD}=0.72 \mu \mathrm{m})$, and at the end of the photoperiod, biovol- 

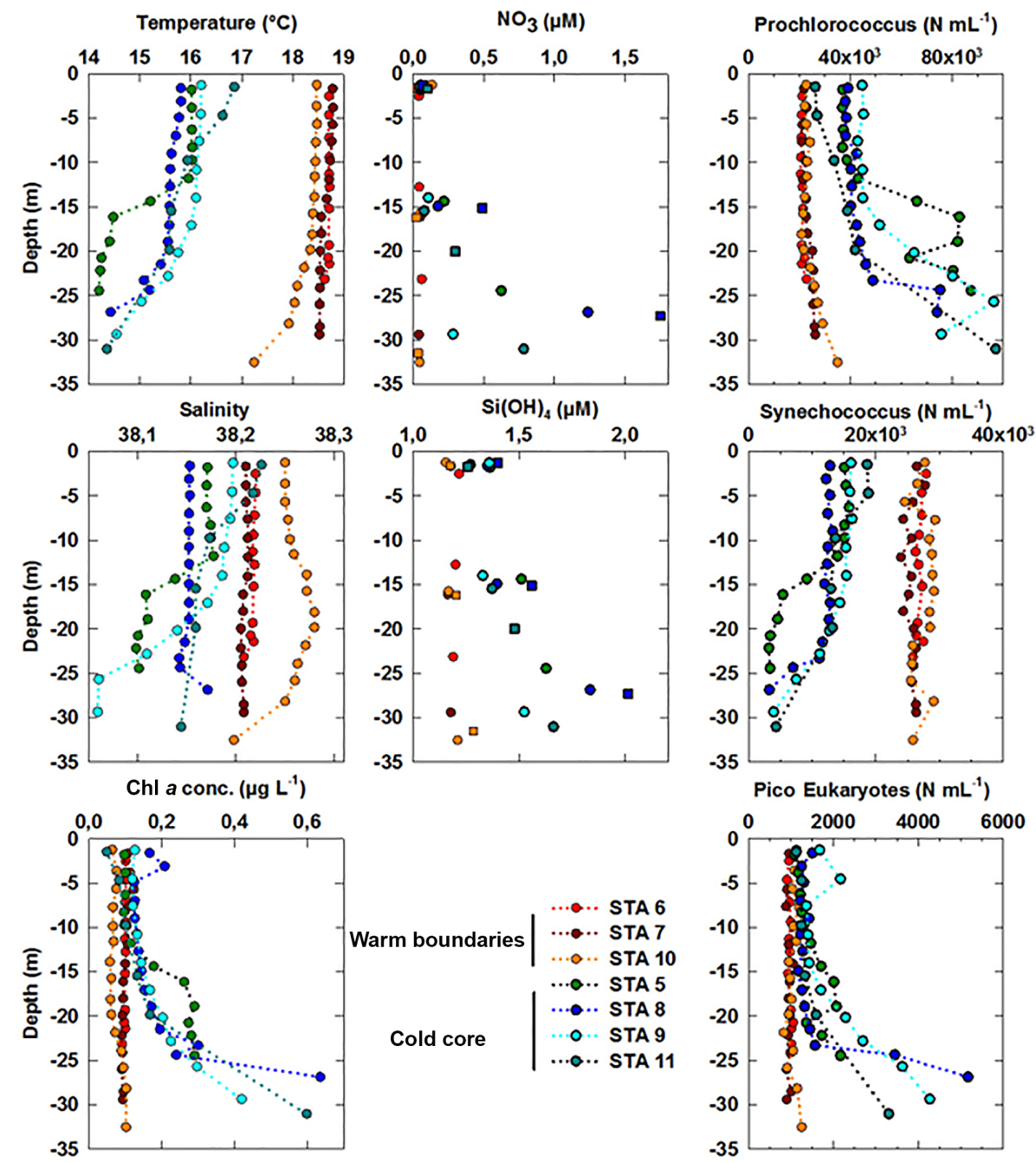

Figure 8. Vertical profiles of temperature (in ${ }^{\circ} \mathrm{C}$ ), salinity and $\mathrm{Chl} a$ concentrations $\left(\right.$ in $\mu \mathrm{g} \mathrm{dm}{ }^{-3}$ ) obtained from the CTD fluorimeter after conversion at the depths where vertical high-resolution sampling was acquired for benchtop flow cytometry analysis using the PASTIS_HVR system. Abundances of Prochlorococcus, Synechococcus and picoeukaryote (PicoE + PicoHighFLR + PicoHighFLO) groups are expressed in cells $\mathrm{cm}^{-3}$. Nutrients were sampled at a different resolution using both the PASTIS_HVR system (circles) and the CTD rosette (squares). Stations performed in cold core surface waters are represented by blue-green colors and those performed in warm boundary surface waters by red-orange colors.

ume reached values of up to $0.60 \mu \mathrm{m}^{3}(\mathrm{ESD}=1.04 \mu \mathrm{m})$. The size distribution variations observed for both populations, with a clear diurnal cycle pattern, highlighted the capacity of single-cell flow cytometry measurements to follow the cellular cycle of these picophytoplanktonic populations. Similar computations were performed on pico- and nano-eukaryote populations, but their size distribution did not show a pattern consistent with the assumption of the size distribution model.

Using a size-structured matrix population model, in situ daily growth rates were estimated from the predicted absolute distribution of cells in size classes, with the continuously observed size distribution as model input. Prochlorococcus and Synechococcus modeled-predicted cell size distributions (Fig. 9c and d) reproduced well the diurnal size distribution cycle and allowed us to derive a specific growth rate $\left(\mu_{\text {size }}\right.$, Table 3$)$ for both populations. For comparison, the median size ratio $\mu_{\text {ratio }}=\ln \left(\bar{v}_{\max } / \bar{v}_{\text {min }}\right)$ (Table 3) was computed. Prochlorococcus and Synechococcus specific growth rates $\mu_{\text {size }}$ were $0.21 \pm 0.01 \mathrm{~d}^{-1}$ and $0.72 \pm 0.01 \mathrm{~d}^{-1}$, and 0.28 and 0.49 for the mean size ratio $\mu_{\text {ratio, }}$, respectively. The Prochlorococcus computed loss rate estimate was $0.30 \mathrm{~d}^{-1}$, while Synechococcus was characterized by a computed loss rate of $0.68 \mathrm{~d}^{-1}$.

The apparent production of these picocyanobacteria $\mathrm{NPP}_{\text {cell }}$ and $\mathrm{NPP}_{\text {size }}$ was computed from the population's intrinsic growth rates (Eqs. 8 and 9), in the absence of particle grazing and sinking and of advective processes, using the approximation of the carbon content $Q_{\mathrm{C} \text {, calc }}$ (Ta- 

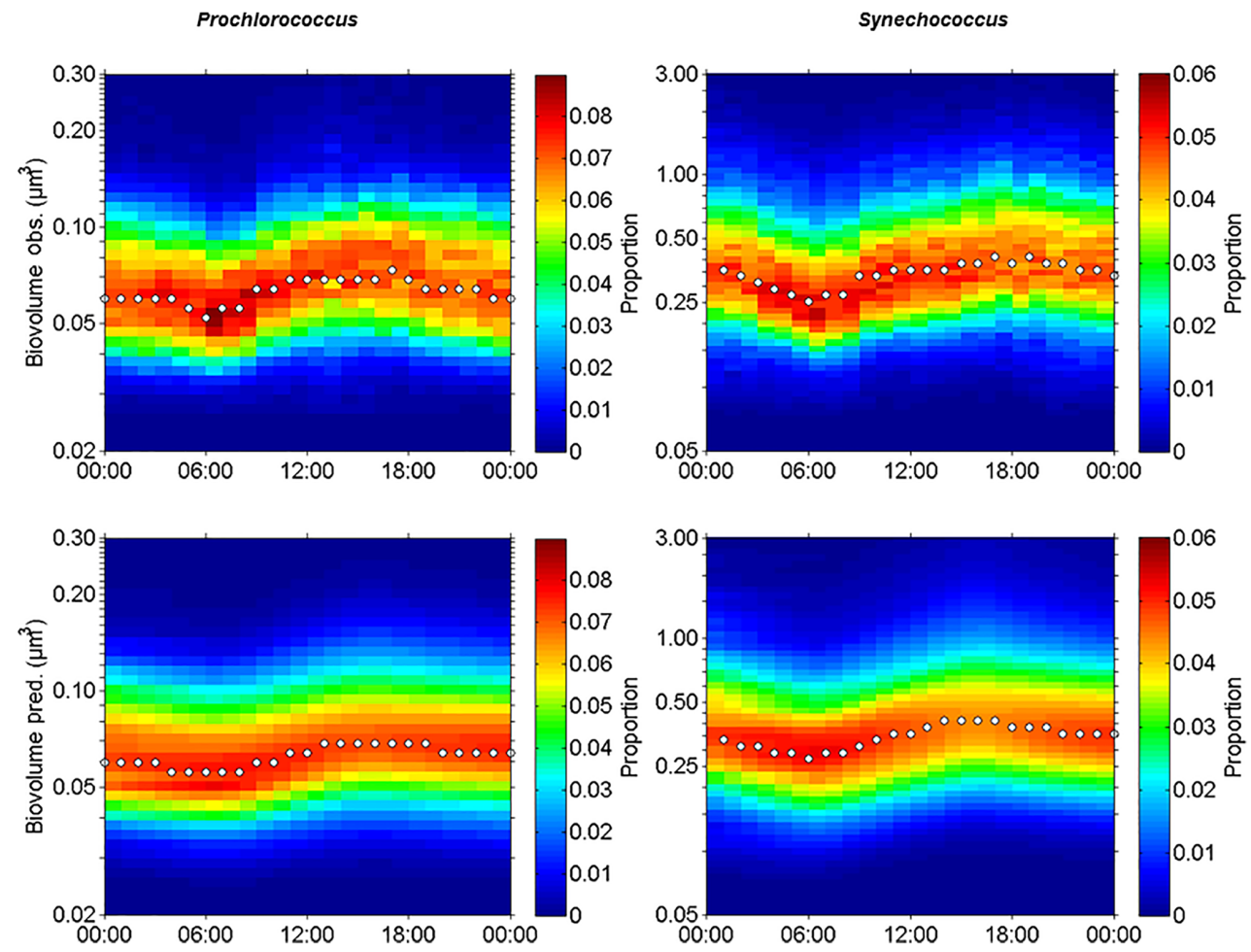

Figure 9. Observed (Obs.) and predicted (Pred.) hourly normalized cell size distributions (in $\mu^{3}{ }^{3}$ ) of Prochlorococcus and Synechococcus from 5 November 00:00 to 6 November 00:00 (local time). White dots indicate the median size of the populations.

ble 2) of the cells newly formed after mitotic division over $24 \mathrm{~h}$. Prochlorococcus $\mathrm{NPP}_{\text {cell }}$ was $0.11 \mathrm{mg} \mathrm{Cm}^{-3} \mathrm{~d}^{-1}$ and the Synechococcus NPP cell estimate was $2.68 \mathrm{mg} \mathrm{Cm}^{-3} \mathrm{~d}^{-1}$ (Table 3) considering mean carbon cellular quota of 25 and $109 \mathrm{fg} \mathrm{C} \mathrm{cell}^{-1}$ for Prochlorococcus and Synechococcus (Table 2). Accounting for the increase in their size distribution during the photoperiod, Prochlorococcus $\mathrm{NPP}_{\text {size }}$ was estimated at $0.13 \mathrm{mg} \mathrm{Cm}^{-3} \mathrm{~d}^{-1}$ and Synechococcus $\mathrm{NPP}_{\text {size }}$ estimated at $2.80 \mathrm{mg} \mathrm{Cm}^{-3} \mathrm{~d}^{-1}$ (Table 3) using the biovolumeto-carbon $a v_{i}^{b}$ relationship for Prochlorococcus and Synechococcus (Table 2).

\section{Discussion}

The Mediterranean Sea represents only $\sim 0.8 \%$ in surface and $\sim 0.3 \%$ in volume as compared to the World Ocean, but hosts between 4 and $18 \%$ of world marine species, making it a biodiversity hotspot (Bianchi and Morri, 2000; Lejeusne et al., 2010). The Mediterranean Sea is a reducedscale laboratory basin for the investigation of processes of global importance (Malanotte-Rizzoli et al., 2014; Pascual et al., 2017) because it is characterized by a complex circulation scheme including deep water formation and intense mesoscale and submesoscale variability (Millot and TaupierLetage, 2005). Mesoscale and submesoscale variability overlays and interacts with the basin and subbasin scales, pro-
Table 3. Prochlorococcus and Synechococcus daily growth rate estimate $\left(\mu_{\text {ratio }}\right)$ computed as the median size ratio $\mu_{\text {ratio }}=$ $\ln \left(\bar{v}_{\max } / \bar{v}_{\min }\right)$, intrinsic growth rate $\left(\mu_{\text {size }}\right)$ and loss rate $(l)$ obtained from Eq. (7). NPP cell and $\mathrm{NPP}_{\text {size }}$ biomass production values obtained from Eqs. (8) and (9), respectively.

\begin{tabular}{lrr}
\hline & Prochlorococcus & Synechococcus \\
\hline$\mu_{\text {ratio }}\left(\mathrm{d}^{-1}\right)$ & 0.28 & 0.49 \\
$\mu_{\text {size }}\left(\mathrm{d}^{-1}\right)$ & 0.21 & 0.72 \\
$l\left(\mathrm{~d}^{-1}\right)$ & 0.30 & 0.68 \\
$\mathrm{NPP}_{\text {cell }}\left(\mathrm{mg} \mathrm{C} \mathrm{m}^{-3} \mathrm{~d}^{-1}\right)$ & 0.11 & 2.68 \\
$\mathrm{NPP}_{\text {size }}\left(\mathrm{mg} \mathrm{C} \mathrm{m}^{-3} \mathrm{~d}^{-1}\right)$ & 0.13 & 2.80 \\
\hline
\end{tabular}

ducing intricate processes representative of complex and still unresolved oceanic systems (Malanotte-Rizzoli et al., 2014; Pascual et al., 2017). The small size of the Mediterranean Sea and the proximity of numerous marine observatories are other outstanding advantages giving its status of a "miniature ocean" laboratory. The Mediterranean Sea is considered an oligotrophic basin (Moutin and Prieur, 2012) and its primary production by phytoplankton is generally low (D'Ortenzio and Ribera d'Alcala, 2009).

The general surface circulation pattern in the western basin of the Mediterranean Sea is characterized by Modified Atlantic Water (MAW) transported from the Algerian basin 
to the Ligurian subbasin (Millot and Taupier-Letage, 2005), flowing in the surface and northward from the western part of Corsica called the Western Corsican Current, and joining the Eastern Corsican Current in the vicinity of Cap Corse to form the Northern Current (Astraldi and Gasparini, 1992; Millot, 1999). A cyclonic gyre is generated by a recirculation of the Northern Current towards the Western Corsican Current. Our study area was located in the center of a cyclonic recirculation within the Ligurian subbasin and forced by atmosphericclimatic conditions (Astraldi et al., 1994). The Ligurian subbasin hydrological regime varies from intense winter mixing to strong thermal stratification in summer and fall. The phytoplankton biomass increases significantly in late winter/early spring, sustained by nutrient fertilization from deep waters, and decreases along with biological activity in summer and fall due to nutrient ( $\mathrm{N}$ and $\mathrm{P}$ ) depletion in surface waters (Marty et al., 2002). In the late summer/early fall season (the time of this present study), the phytoplankton community structure in the Ligurian subbasin is dominated by small-sized phytoplankton species (such as Prochlorococcus, Synechococcus, and pico- and nano-eukaryotes; Marty et al., 2008).

\subsection{Physical origins and dynamics of the fine-scale structure investigated during OSCAHR}

Both ADCP and AVISO derived surface current directions and intensities suggested that the sampled cold core mesoscale structure was associated with a cyclonic gyre generated by a recirculation of the Northern Current towards the Western Corsican Current (Fig. 1, AVISO). Besides a generally cyclonic circulation pattern between the French coast and Corsica that geostrophically domed the isopycnals, Ekman pumping is likely to have played an important role since strong wind events were observed before the OSCAHR cruise, and previous studies (Gaube et al., 2013) have highlighted Ekman pumping's impact on ocean biogeochemistry. Ekman pumping calculated using both WRF and scatterometer wind estimates (Fig. 10) suggested that, besides the strong wind event occurring during the first day of the cruise, the region has experienced several wind events 2 weeks before the cruise characterized by vertical velocities peaking to 3$4 \mathrm{md}^{-1}$ inducing a strong decline in SST. Furthermore, the time series of vertical velocities highlighted that the cold water "patch" experienced almost constantly negative (i.e., upwarding) vertical velocities for about 1 month (Fig. 10).

The shallowing of the thermocline in the central part of the cyclonic structure associated with low SST in the cold patch was shown by the MVP salinity and temperature profiles (Fig. 3). Low-salinity waters at the surface of the cold patch support the Ekman pumping process hypothesis. Within the warm boundaries, a subsurface layer of low-salinity waters $(<38.10)$ spreading off below the thermocline and reaching the surface in the cold core is observed for each MVP and CTD deployment. The origin of these low-salinity sub-

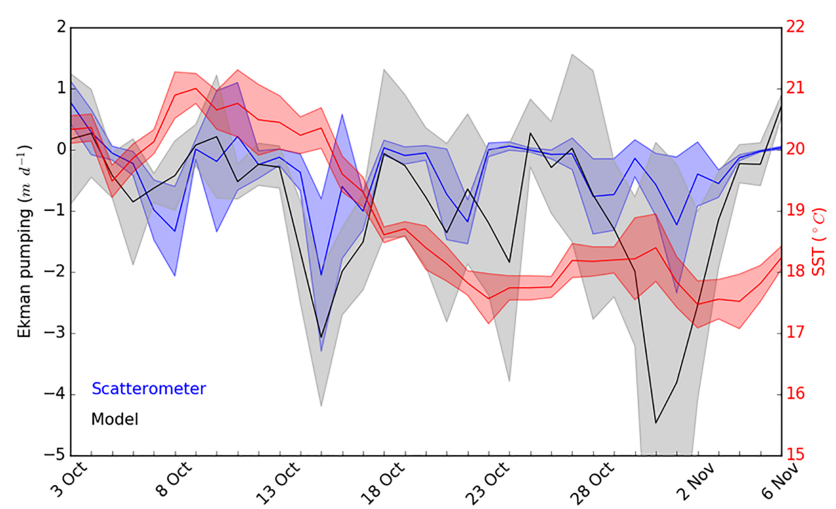

Figure 10. Ekman pumping vertical velocities (in $\mathrm{md}^{-1}$ ) computed from scatterometer (in blue) and atmospheric model (in black) wind speeds and mean SST (in red, in ${ }^{\circ} \mathrm{C}$ ) in our study area from 3 October to 6 November. Shade areas represent the SD relative to each measurement. Negative Ekman pumping values represent upward vertical velocities.

surface waters remains unclear. The cyclonic circulation in the Ligurian subbasin induced by the intense coastal currents along the Italian and French coasts (Astraldi et al., 1994) is supposed to isolate the central Ligurian subbasin from direct riverine inputs, such inputs being in addition particularly poor in this area (Migon, 1993). Goutx et al. (2009) reported similar observations for the same period (13 October 2004) in the Ligurian subbasin $\left(43.25^{\circ} \mathrm{N}, 8^{\circ} \mathrm{E}, 48 \mathrm{~km}\right.$ offshore), close to our study area, as well as Marty et al. (2008). Further investigations might be done to find the origin of this low-salinity subsurface layer.

As mentioned by McGillicuddy (2016), the superposition of a wind-driven Ekman flow on a mesoscale velocity field can cause ageostrophic circulation involving significant vertical transport (Niiler, 1969; Stern, 1965). The cyclonic recirculation produced a zone of divergence in the central zone of the Ligurian Sea which domed the main pycnoclines, thereby shallowing the mixed layer (Sournia et al., 1990; Estrada, 1996; Nezlin et al., 2004). This process resulted in the fertilization of the upper mixed layer with nutrient-rich upwelled waters (Miquel et al., 2011). Remote-sensing (SST, $\mathrm{Chl} a$ ), model (AVISO, WRF), continuous surface measurements and MVP profiles support the Ekman pumping hypothesis induced by a strong wind event. The resulting upwelled subsurface cold water fertilized surface waters, which increased Chl $a$ concentration (Figs. 1, 2 and 6) and the primary production (Sournia et al., 1990) that in turn sustain higher trophic levels (Warren et al., 2004).

Furthermore, surface warm boundary waters were subdivided into two distinct types (Table 1): type 1 (in red in Figs. 6, 10 and 11) and type 2 (in orange), according to their physical and biogeochemical properties. Cold patch water (Fig. 7d) signatures had a SST lower than $17^{\circ} \mathrm{C}$ and a SSS lower than 38.23. Type 1 warm boundary waters were de- 
fined with a SST higher than $17^{\circ} \mathrm{C}$ and a SSS higher than 38.23. Type 2 warm boundary waters were characterized by a SST higher than $18^{\circ} \mathrm{C}$ and a SSS lower than 38.24.

\subsection{Nutrients and Chl $a$ distribution}

In the cold core, nitrate and silicate started to increase below $15 \mathrm{~m}$ (Fig. 8). The first detectable phosphate concentrations appeared below $50 \mathrm{~m}$ (>0.2 $\mu \mathrm{mol} \mathrm{dm}{ }^{-3}$, Fig. S2). However, surface cold core waters contained more autotrophic biomass than warm boundary waters, as shown by surface $\mathrm{Chl} a$ concentrations (Figs. 2 and 6, Table 1). In the cold core waters, the nutrient availability starting around $15-20 \mathrm{~m}$ in depth sustained an increase in Chl $a$ of up to $0.6 \mu \mathrm{g} \mathrm{dm}^{-3}$ at $30 \mathrm{~m}$ in depth (Fig. 8), while in warm boundary waters, a deeper MLD kept the DCM below $30 \mathrm{~m}$ (Fig. S1). This later was characterized by lower Chl $a$ values in the warm boundary, which was limited by both the nutrient availability and the amount of light availability for phytoplankton cells. Within the Ligurian subbasin, the DCM is shallower than in other oligotrophic areas: a maximum of $60 \mathrm{~m}$ in depth (Marty et al., 2002) against $150 \mathrm{~m}$ or more in the tropical oligotrophic $\mathrm{Pa}-$ cific Ocean (Claustre et al., 1999), and $\sim 100 \mathrm{~m}$ in the oligotrophic Atlantic gyres (Marañón et al., 2003). The euphotic depth (Zeu $\sim 70 \mathrm{~m}$, Fig. S2) in the Ligurian subbasin was deeper than the MLD and the DCM during all of the year (Marty et al., 2002), except in winter. The variation of the nitracline depth induced by the cyclonic circulation and Ekman pumping appeared to be the most relevant factor controlling this vertical and horizontal biological distribution variability.

\subsection{High-resolution dynamics of phytoplankton groups}

\subsubsection{Phytoplankton functional group description}

The picocyanobacteria Prochlorococcus and Synechococcus are the smallest and most abundant photoautotroph in the oceans (Waterbury et al., 1986; Olson et al., 1988; Chisholm et al., 1992) and have a key role in a variety of ecosystems, particularly in oligotrophic ones (Partensky et al., 1999a). The observations reported in this study are, to the best of our knowledge, the first to correctly resolve Prochlorococcus abundance in surface waters using a CytoSense AFCM due to some improvements of the instruments (a carbon activated filter to reduce the optical background of the seawater, a more powerful laser beam to improve the side scatter intensities of these very small cells). Prochlorococcus mean ESD and the associated biovolume of $0.5 \pm 0.1 \mu \mathrm{m}$ and $0.07 \pm 0.03 \mu \mathrm{m}^{3}$, respectively (Table 2 ), were in the lower range of 0.5 to $0.9 \mu \mathrm{m}$ and 0.03 to $0.38 \mu \mathrm{m}^{3} \mathrm{ESD}$ and biovolume values reported in previous studies (Morel et al., 1993; Partensky et al., 1999b; Shalapyonok et al., 2001; Ribalet et al., 2015). Sieracki et al. (1995), DuRand et al. (2001) and Shalapyonok et al. (2001) noticed that Prochlorococcus cell diameter and biovolume were generally lower in the surface mixed layer $\left(0.45-0.60 \mu \mathrm{m}\right.$ and $\left.0.05-0.11 \mu \mathrm{m}^{3}\right)$ than in deeper waters $\left(0.75-0.94 \mu \mathrm{m}\right.$ and $\left.0.21-0.43 \mu \mathrm{m}^{3}\right)$. In this study, Synechococcus mean ESD and an associated biovolume of $0.9 \pm 0.2 \mu \mathrm{m}, 0.46 \pm 0.38 \mu \mathrm{m}^{3}$, respectively (Table 2 ), were in the same range of 0.8 to $1.2 \mu \mathrm{m}$ and 0.25 to $1.00 \mu \mathrm{m}^{3}$ as ESD and biovolume values reported in previous studies (Morel et al., 1993; Shalapyonok et al., 2001; Sosik et al., 2003; Hunter-Cevera et al., 2014). DuRand et al. (2001) and Shalapyonok et al. (2001) reported that deeper Synechococcus can also be characterized by higher mean cell diameters. To explain our observations, the literature reveals that Prochlorococcus can belong to the photoadapted high-light (HL) ecotype characterized by less $\mathrm{Chl} a$ content, i.e., less FLR, or to the low-light (LL) ecotype characterized by higher Chl $a$ content, i.e., higher FLR (Moore and Chisholm, 1999; Garczarek et al., 2007; Partensky and Garczarek, 2010). Usually, the HL ecotype occupies the upper part of the euphotic zone, while the LL ecotype dominates the bottom of the euphotic layer. The occurrence of a Prochlorococcus population with significantly higher FLR (and/or SWS) values, which might be representative of the LL ecotype, was never observed in surface waters (Fig. 12 for AFCM and Fig. S4 for conventional flow cytometry). FLR distribution of Prochlorococcus obtained from samples analyzed by conventional flow cytometry in the cold core and warm boundary waters over the first $35 \mathrm{~m}$ (Fig. S5) revealed that distinct normal distributions of FLR were observed in cold core waters between surface and mixed layer depth samples. The presence of both ecotypes (HL and LL) around the mixed layer depth in cold core waters (from 15 to $20 \mathrm{~m}$ in depth) was suggested from the Prochlorococcus FLR distributions, even when any clear bimodal distribution of FLR (or SWS, data not shown) signals were observed (Figs. S4 and S5). The DCM (i.e., $40 \mathrm{~m}$ in depth), where the LL ecotype is supposed to be the main ecotype, was sampled on only one occasion, during the STA11 CTD rosette (Figs. S2, S4 and S5). Campbell and Vaulot (1993) clearly show that a bimodal distribution of FLR intensities can be observed when two ecotypes are present together in similar proportion around the DCM. By similar, we mean a sufficient abundance of both ecotypes, which makes it possible to clearly identify the bimodal distribution of FLR. Blanchot and Rodier (1996) also identify such a bimodal distribution in a few locations. They clearly explained that in other locations, ecotype (sub-population) cooccurrence cannot be observed from bimodality of the FLR distribution because both ecotypes were not abundant enough to be clearly seen. In these locations both ecotypes still existed, but their concentrations were very different and thus the two peaks could not be seen, the larger peak overpassing the smaller one. Synechococcus ecotype distribution is not characterized by a clear depth partitioning: their distribution appears to be principally controlled by water temperature and latitude (Pittera et al., 2014). Mella-Flores et al. (2011) and Farrant et al. (2016) reported that in the Mediterranean Sea, HLI and III clades were the dominant ecotypes in surface 
waters for Prochlorococcus and Synechococcus, respectively, whereas LLI and I/IV clades were the main Prochlorococcus and Synechococcus ecotypes present in deep waters. Obviously, further analyses of OSCAHR samples performed at the molecular level would have been necessary to validate these explanations or not.

Pico- and nano-eukaryotes were distinguished into six cytometric groups based on their scattering (FWS) and fluorescence (FLR and FLO) properties, although pico- and nanoeukaryotes include cells of several taxa (Simon et al., 1994; Worden and Not, 2008; Percopo et al., 2011). As mentioned in Sect. 3.3, PicoE and NanoE (Fig. 4) were the main groups represented in terms of abundances, and their variability drove the whole dynamics of pico- and nano-eukaryote size groups across the cold core and warm boundary waters. If flow cytometry is ataxonomic, it has been reported in several previous studies that the picoeukaryote size fraction in the Mediterranean Sea is represented by prasynophytes, alveolates, picobiliphytes, haptophytes and stramenopiles (Not et al., 2009), in the size spectrum $0.9 \mu \mathrm{m}$ (Ostreococcus taurii) $-3.5 \mu \mathrm{m}$ (Phaeocystis cordata). A global compilation from Vaulot et al. (2008) reported a picoeukaryote description in an extended range of $0.8-3 \mu \mathrm{m}$, which corresponds to the mean ESD of $2.6 \pm 0.5 \mu \mathrm{m}$ observed in our study.

The mean ESD of the main nanoeukaryote functional group observed, NanoE (Fig. 4), was $4.1 \pm 0.5 \mu \mathrm{m}$ (Table 2), a relatively small size considering the $2-20 \mu \mathrm{m}$ range characterizing nanoeukaryotes in the literature. In the northwestern Mediterranean Sea, according to the abundant literature, the $2-10 \mu \mathrm{m}$ size fraction is composed, in importance, of diverse genera of Coscinodiscophyceae (Arcocellulus: 3.5-8.7 $\mu \mathrm{m}$, Minidiscus: 2.7-4.3 $\mu \mathrm{m}$, Thalassiosira: $2.7-$ $16.3 \mu \mathrm{m})$, Dinophyceae (Heterocaspa: 7.0-10.6 $\mu \mathrm{m}$ ), Coccolithophyceae (Anthosphaera: $2.9 \mu \mathrm{m}$, Gephyrocapsa: $4.7-$ $8.3 \mu \mathrm{m}$ ), and Prymnesiophyceae (Chrysochromulina: $3.2-$ $4.0 \mu \mathrm{m})$ (Percopo et al., 2011). The NanoHighFLO functional group (Fig. 4), characterized by high orange fluorescence, presented similarities to the well-defined cryptophycean taxa, diagnosed by the presence of orange fluorescing phycoerythrin. NanoHighFLO cells had mean ESD lower than $5 \mu \mathrm{m}$. Small nanoflagelattes dominate the nanophytoplankton size group in terms of cell concentrations most of the year in oligotrophic Mediterranean Sea waters (SiokouFrangou et al., 2010).

Microphytoplankton abundances reported in this study (20-30 cells $\mathrm{cm}^{-3}$ ) could appear high regarding previously reported cell concentrations ranging between 1 and 5 cells $\mathrm{cm}^{-3}$ (Gomez and Gorsky, 2003). MicroE cells, as defined manually on cytograms, presented ESDs of between 10 and $20 \mu \mathrm{m}$, which could be considered large-sized nanophytoplankton cells. As mentioned by Siokou-Frangou et al. (2010), single cells of colonial diatoms smaller than $20 \mu \mathrm{m}$ are commonly observed in Mediterranean waters and are treated separately from the nanophytoplankton because of their larger functional size and distinct ecological role. The
MicroHighFLO cluster had mean ESD $>20 \mu \mathrm{m}$, and was considered the only true microphytoplankton component. MicroHighFLO abundances $\left(<5\right.$ cells cm ${ }^{-3}$, with a peak of up to 20 cells $\mathrm{cm}^{-3}$ ) were in better agreement with those generally observed in similar oligotrophic surface waters (Gomez and Gorsky, 2003; Vaillancourt et al., 2003; Girault et al., 2013a). Similarly low microphytoplankton abundances $\left(<5\right.$ cells $\mathrm{cm}^{-3}$ ) were observed in a coastal station of the northwestern Mediterranean Sea, even during the spring bloom (Gomez and Gorsky, 2003), and low abundances, $4 \pm 5$ and $3.6 \pm 7 \mathrm{cell} \mathrm{cm}^{-3}$, were reported by Dugenne (2017) in the northwestern Mediterranean Sea. The microphytoplankton in the northwestern Mediterranean Sea is rather dominated by diatoms and dinoflagellates (Ferrier-Pagès and Rassoulzadegan, 1994; Gomez and Gorsky, 2003; Marty et al., 2008).

\subsubsection{Horizontal and vertical distributions of the phytoplankton community structure}

A clear distinct tri-dimensional distribution of phytoplankton abundances was observed between the cold core and warm boundary waters. Despite the apparent constant oligotrophy of the surface waters (Sect. 3.1), high variations in phytoplankton assemblage structuration were in evidence in this study, consistent with previous studies led in similar oligotrophic areas (Marañón et al., 2003; Girault et al., 2013b). The cold core richness, in terms of $\mathrm{Chl} a$ concentration, was sustained by higher Prochlorococcus, picoeukaryote and nanoeukaryote abundances (Figs. 5 and 6, Table 1). By contrast, high abundances of Synechococcus characterized the warm boundaries. The contrasted surface distribution between Prochlorococcus and Synechococcus populations is clearly visible in Fig. 6. As displayed by their vertical distribution (Fig. 8), Prochlorococcus and picoeukaryote higher abundances in the cold core waters resulted from upwelled nutrient-rich waters. Maximal abundances above 80000 and 4000 cells cm $^{-3}$ were recorded for Prochlorococcus and picoeukaryotes, respectively, at the DCM depth, where nitrate was not limiting but irradiance decreased $(10-30 \%$ of surface PAR only). By contrast, Synechococcus presented low abundances at the DCM $\left(<5000\right.$ cells cm$^{-3}$, Fig. S2 $)$ but maximal abundances $\left(\sim 30000\right.$ cells $\left.\mathrm{cm}^{-3}\right)$ within the warm boundary mixed layer (Fig. 8). Prochlorococcus and Synechococcus have been demonstrated to occupy different light niches over the water column (Agustí, 2004). Synechococcus are particularly adapted to depleted nitrate and phosphate conditions (Moutin et al., 2002; Michelou et al., 2011) and are high-light adapted due to less efficient accessory pigments (Moore et al., 1995). To acquire the necessary energy to grow, they have developed efficient ways to cope with light and UV stress, conversely to Prochlorococcus (MellaFlores et al., 2012), which are able to grow deeper in the euphotic zone (Olson et al., 1990a). Marty et al. (2008) reported similar vertical distribution patterns at the DYFAMED sta- 
tion in the central Ligurian subbasin under late summer/early fall conditions and such vertical distribution of the picophytoplankton has been described and explained in various other oligotrophic environments (Olson et al., 1990a; Campbell et al., 1997; Partensky et al., 1999a, b; DuRand et al., 2001; Girault et al., 2013b). As a matter of fact, we have reported similar Prochlorococcus and Synechococcus abun-

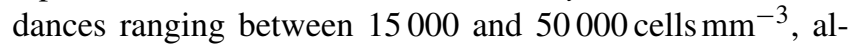
though 1 or 2 orders of magnitude between Prochlorococcus and Synechococcus abundances have been generally observed in strong to ultra-oligotrophic areas.

\subsubsection{Contribution to total red fluorescence and $\mathrm{C}$ biomass}

The FLR and C biomass contributions of Prochlorococcus, Synechococcus, picoeukaryotes and nanoeukaryotes present opposite patterns to the one in abundances previously described between the cold core and warm boundary waters. Nanoeukaryotes were the main contributors $(>50 \%)$ in terms of pigment content (defined by FLR) and biomass. Marty et al. (2008) reported a $10 \%$ relatively constant contribution of $\mathrm{C}$ biomass for microphytoplankton in the same area during the late summer/early fall based on pigment data analysis. Abundances of Prochlorococcus and Synechococcus throughout cold core and warm boundary surface waters were on the same order of magnitude as in their study $\left(10^{5}\right.$ cells $\left.\mathrm{cm}^{-3}\right)$, but FLR and biomass contributions of Prochlorococcus were 5 to 10 times lower. When this contribution is integrated over the euphotic layer, studies performed in a similar oligotrophic environment indicated a larger contribution of Prochlorococcus to Chl $a$ and/or biomass compared to Synechococcus at this time of the year (Olson et al., 1990a; DuRand et al., 2001; Marty et al., 2008). In our study, as only surface data were considered, excluding the DCM phytoplankton assemblage, it may explain the higher contribution of Synechococcus compared to Prochlorococcus.

\subsubsection{Biology as a tracer on a fine scale of water masses}

Synechococcus relative contribution to total FLR, as defined by AFCM, tends to overestimate their importance compared to their contribution calculated from their cellular $\mathrm{C}$ quota. Their abnormally high FLR (Fig. 7a, orange dots in Fig. 7b) caused a sudden increase in FLR Total (Fig. 7b), while no shift in red fluorescence was shown by the TSG in these type 2 warm boundary waters (Sect. 4.1). Synechococcus pigment composition is characterized by phycoerythrin (PE), with a fluorescence emission peak at $575 \mathrm{~nm}$, and phycocyanin (PC), with a fluorescence emission peak at $650 \mathrm{~nm}$. Those pigments vary depending on the strains or the growing conditions (Olson et al., 1990b). Since the TSG fluorometer collects fluorescence emission $>685 \mathrm{~nm}$ and the AFCM collects $>652 \mathrm{~nm}$, the relatively higher FLR contribution could be explained by the $\mathrm{PC}$ red fluorescence emission into the red fluorescence channel collected by the AFCM. As some samples were also analyzed on a FACSCalibur equipped with a $633 \mathrm{~nm}$ laser beam, it was possible to measure the red fluorescence induced by $\mathrm{PC}$ and thus calculate the ratio $\mathrm{PC} / \mathrm{PE}$. It occurred that the Synechococcus population observed in type 2 waters (stations 6 and 7) had a higher PC : PE ratio (about 0.33 , data not shown) compared to other stations $(<0.27$, data not shown). The ratio $\mathrm{PC}: \mathrm{PE}$ varies as a response to photoacclimation, as well as to chromatic adaptation (Dubinsky and Stambler, 2009; Stambler, 2014).

These Synechococcus populations were retrieved in the northern corners of our study area (Fig. 7c), characterized by warmer SST $\left(>18.5^{\circ} \mathrm{C}\right)$ and lower SSS values $(<38.24)$ than type 1 warm boundary waters. Besides their apparently different physical properties, type 1 and 2 waters remained relatively close in terms of TSG fluorescence and phytoplankton abundances (Fig. 11). Surface silicate concentrations in type 2 waters were the lowest observed (Fig. 11d). As mentioned above, only a few phytoplankton species requiring silicate (i.e., diatoms) were observed in the Ligurian subbasin at this time of the year, meaning that the silicate concentration values observed were unlikely to be induced by phytoplankton silicate consumption.

The observed increase in Prochlorococcus, Synechococcus and picoeukaryote mean cell $\mathrm{FLR}_{\mathrm{m}}$ in type 2 surface warm boundary waters (Fig. 11i-k) might result from photoacclimation to depth by increasing their cell size and Chl $a$ per cell content (Olson et al., 1990b; Campbell et al., 1997; DuRand et al., 2001; Dubinsky and Stambler, 2009; Stambler, 2014), suggesting a recent upwelling of deeper waters. However, they were characterized by the highest SST recorded during the campaign, which runs counter to the deep origin of the water mass. Moreover, deep Prochlorococcus and Synechococcus cells located below the thermocline at the DCM were characterized by a $\sim 5$-fold higher FLR compared to surface cells (Fig. S4). Vertical Synechococcus fluorescence values recorded by benchtop flow cytometry at stations 6 and 7 (type 2 warm boundary waters) were characterized by the highest values, down to $10 \mathrm{~m}$ in depth, but still remain below the highest fluorescence values recorded below the DCM. This rejects the hypothesis of upwelled low-light photoacclimated populations. The phytoplankton community in surface warm boundary waters 2 might then be considered a distinct phytoplankton population, which grew in a different environment than warm boundary waters 1 .

Type 1 and type 2 warm boundary waters were not significantly distinguishable regarding SST/SSS (Fig. 7d), and by combining it with the surface circulation patterns and FLR anomalies (Fig. 7a), we can hypothesize that type 2 warm boundary waters could correspond to a patch of surface Tyrrhenian Sea brought by the Eastern Corsica Current trapped in MAW waters from the Western Corsica Current. Although both warm boundary waters reflected similar biogeochemical growing conditions and phytoplankton 

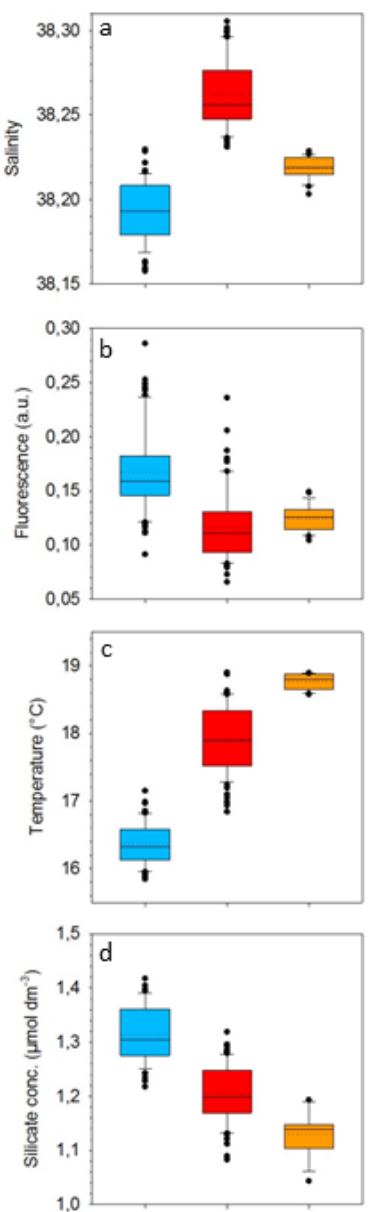
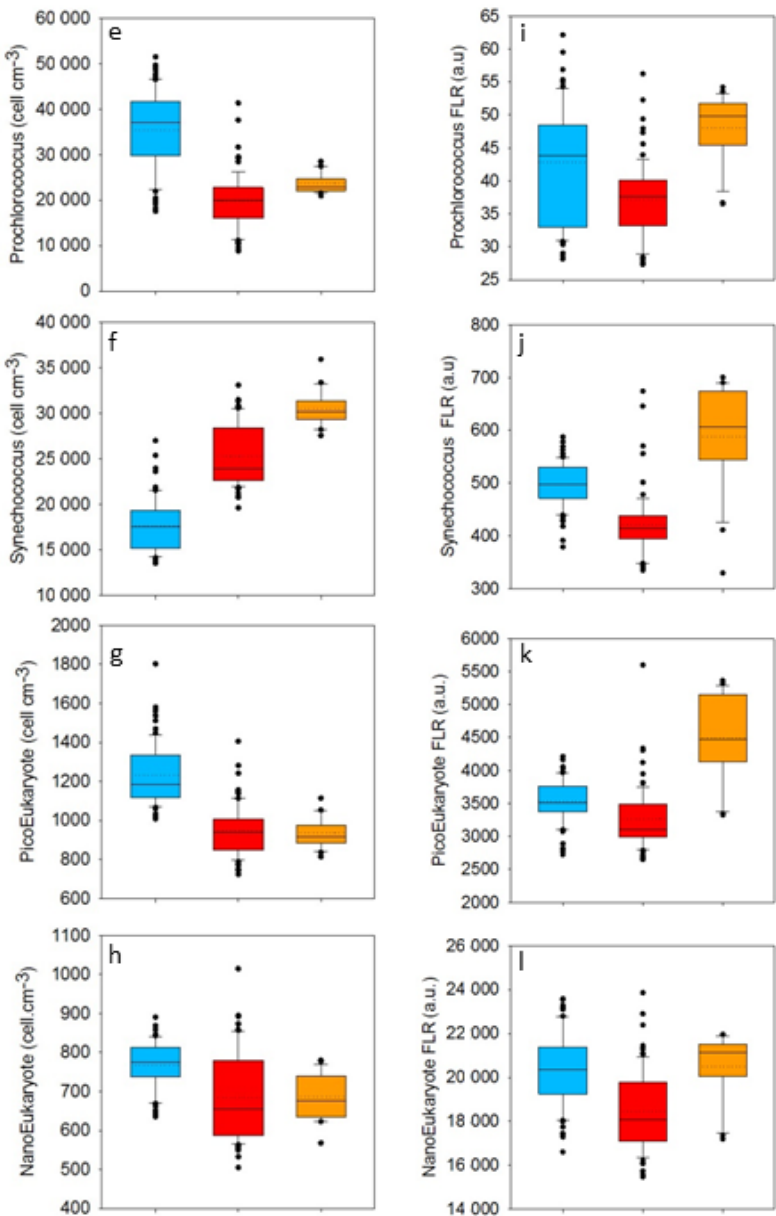

Figure 11. Boxplots of SSS, fluorescence (in a.u.), SST (in ${ }^{\circ} \mathrm{C}$ ) and silicate concentration (in $\mu \mathrm{moldm}{ }^{-3}$ ) in cold core (in blue) and warm boundary 1 (in red) and 2 (in orange) surface waters. Prochlorococcus, Synechococcus, picoeukaryote (PicoE) and nanoeukaryote (NanoE) abundances (in cell $\mathrm{cm}^{-3}$ ) and specific mean red fluorescence $\left(\mathrm{FLR}_{\mathrm{m}}\right)$ in the same hydrographical provinces are also represented with boxplots. The boundary of the box closest to zero indicates the 25 th percentile, the black line within the box marks the median, the dashed line indicates the mean and the boundary of the box farthest from zero indicates the 75th percentile. Error bars above and below the box indicate the 90th and 10th percentiles, and outlying points are represented. The number of observations on which these boxplots are based is reported in Table 1.

group abundances, the distinct optical properties of phytoplankton groups recorded by flow cytometry combined with high-resolution observations could be evidence of a different (bio)geographical water mass origin.

\subsection{Flow cytometry and productivity estimates}

The application of a matrix growth population model based on high-frequency AFCM measurements in warm boundary surface waters provides estimates of daily production (division rate) and loss rate for Prochlorococcus and Synechococcus populations. The low in situ growth rate obtained for Prochlorococcus $\left(\mu_{\text {size }}=0.21 \mathrm{~d}^{-1}\right)$ and the higher growth rate $\left(\mu_{\text {size }}=0.72 \mathrm{~d}^{-1}\right)$ got for Synechococcus corroborate their surface distribution pattern. The combination of surface growth rate and the population's vertical distri- bution suggests that Prochlorococcus growth was limited in warm boundary surface waters by more intense light conditions, whereas Synechococcus cells were more particularly adapted. Synechococcus growth rate was larger than one division per day $\left(>0.69 \mathrm{~d}^{-1}\right)$. As expected for an asynchronous population, the Synechococcus growth rate estimate from differences in minimal and maximal values of biovolume $\left(\mu_{\text {ratio }}=0.49\right)$ was smaller than the one retrieved from the size distribution variations $\mu_{\text {size }}$. For Prochlorococcus, both growth rates were characterized by low values. Low size variations, close to the limits of detection of the flow cytometer, might cause eventual bias in the $\mu_{\text {ratio }}$ calculation. It could explain why $\mu_{\text {ratio }}\left(0.28 \mathrm{~d}^{-1}\right)$ was slightly higher than $\mu_{\text {size }}$. Synechococcus growth rate was consistent with values of $0.48-0.96 \mathrm{~d}^{-1}$ reported by Ferrier-Pages and Rassoulzadegan (1994) and with the value of $0.6 \mathrm{~d}^{-1}$ reported 
by Agawin et al. (1998), both measured in the same period in surface waters of coastal stations of the northwestern Mediterranean Sea. Prochlorococcus growth rate was in the same range as the growth rate values (between 0.1 and $0.4 \mathrm{~d}^{-1}$ ) reported by Goericke et al. (1993) during summer and winter in surface waters of the Sargasso Sea. Vaulot et al. (1995) and Liu et al. (1997) measured Prochlorococcus growth rates of $0.5-0.7 \mathrm{~d}^{-1}$ and $0.45-0.60 \mathrm{~d}^{-1}$, respectively, in oligotrophic surface waters of the equatorial and subtropical Pacific, with abundances ranging from 50000 to 200000 cells cm$^{-3}$. Riballet et al. (2015) found a linear relationship between SST and growth rate in October in the subtropical Pacific, with a growth rate value of $\sim 0.4 \mathrm{~d}^{-1}$ at $18^{\circ} \mathrm{C}$. Vaulot et al. (1995) reported maximal growth rate values at $30 \mathrm{~m}$ in depth, where Prochlorococcus abundances were the highest. Moore et al. (1995) noticed that LL Prochlorococcus strain growth could be limited by high light intensity and grew faster at lower light levels, whereas HL strain was photoinhibited only at the highest growth irradiance tested. Based on the literature, on the mean FLR surface values obtained with the AFCM (Fig. 12) and on the single-cell FLR distribution over the water column (Fig. S4), it is very likely that the HL Prochlorococcus strain was the prevailing strain in warm boundary surface waters. The small growth rate of $0.21 \mathrm{~d}^{-1}$ suggested that the surface layer was not the optimal environment at this time of the year for the growth of the Prochlorococcus population observed. This weak growth rate might be linked to the relatively low Prochlorococcus abundances compared to Synechococcus abundances reported in this study. Indeed, in oligotrophic areas, 1 or 2 orders of magnitude have been generally observed between Prochlorococcus and Synechococcus abundances. Higher Prochlorococcus growth rates than those estimated in surface waters by AFCM might be observed at the DCM, where maximal abundances were indeed observed.

Prochlorococcus loss rate $\left(0.30 \mathrm{~d}^{-1}\right)$ was higher than its growth rate during our study, suggesting that loss processes in these surface waters tended to control the Prochlorococcus population abundance, resulting in a decrease in abundance. In the same time, Synechococcus loss rate was slightly lower $\left(0.68 \mathrm{~d}^{-1}\right)$ than its growth rate. Calculated loss rates include both biological factors (predation, viral lysis) and physical factors (removal or addition of cells through sedimentation, or physical transport). Our loss and growth rate estimates were relatively similar for both Prochlorococcus and Synechococcus populations. Similar observations were made by Hunter-Cevera et al. (2014) throughout a year on natural Synechococcus populations, using a similar approach. Ribalet et al. (2015) reported a synchronization of Prochlorococcus cell production and mortality with the day-night cycle in the subtropical Pacific gyre, which likely enforces ecosystem stability in oligotrophic ecosystems. In these ecosystems with limited submesoscale instabilities, picocyanobacteria abundances are relatively constant (Partensky et al., 1999a), as well as biogeochemical characteristics, on 1 to a few days.
The apparent equilibrium of cell abundances of these systems suggests that growth and loss processes are tightly coupled, which helps to stabilize open ocean ecosystems (Partensky et al., 1999a; Ribalet et al., 2015).

Despite a similar range of abundances of both picocyanobacteria $\left(10000-20000\right.$ cells $\left.\mathrm{cm}^{-3}\right)$, the apparent productions $\mathrm{NPP}_{\text {size }}$ and $\mathrm{NPP}_{\text {cell }}$ of Prochlorococcus and Synechococcus (Table 3) indicate that Synechococcus contribution to net C uptake was 20-25 times higher than Prochlorococcus in surface warm boundary waters. Following the growth rate difference previously described, it may reflect the fact that environmental conditions in these surface waters favor the production of Synechococcus cells. Our NPP estimates for Synechococcus (2.68 $\mathrm{mg} \mathrm{Cm}^{-3} \mathrm{~d}^{-1}$, Table 3) were consistent with gross production between 1 and 4 $\mathrm{mgCm} \mathrm{Cm}^{-3} \mathrm{~d}^{-1}$ reported by Agawin et al. (1998) in the northwestern Mediterranean Sea in the same period. Marty et al. (2008) estimates of primary production in the Ligurian subbasin in summer/fall yielded values of between 8 and $16 \mathrm{mg} \mathrm{Cm}^{-3} \mathrm{~d}^{-1}$ in surface waters. According to these estimates, apparent production of Prochlorococcus and Synechococcus accounted for $0.5-1 \%$ and $17-33 \%$ of primary production, respectively, which is consistent with their relative contributions to (i) total fluorescence of 2.5 and $33.3 \%$, respectively, and (ii) to $\mathrm{C}$ biomass of 4 and $22 \%$, respectively, in surface warm boundary waters mentioned in Sect. 3.4. Picocyanobacteria apparent net production rates obtained from different calculations $\left(\mathrm{NPP}_{\text {size }}\right.$ and $\mathrm{NPP}_{\text {cell }}$, Eqs. 8 and 9) provide similar specific $\mathrm{C}$ uptake rates, meaning that the quantity of $\mathrm{C}$ assimilated during the photoperiod is strictly equivalent to the biomass of newly formed cells after mitosis. This result strengthens the characterization of oligotrophic ecosystems in which populations follow a daily dynamic at equilibrium.

However, our apparent production estimates for both Prochlorococcus and Synechococcus have several limitations. The successive conversions from FWS to biovolume and then to $\mathrm{C}$ contents remain a substantial source of uncertainty, although our cellular $\mathrm{C}$ quotas are in agreement with the literature (Table 2). Recent advances in flow cytometry provide direct measurements of specific phytoplankton biomass on sorted populations (Graff et al., 2012). Growth rates do not account for size-specific removal processes (selective grazing, sinking rates). Size-selective grazing may alter in situ growth rates by up to $20 \%$ of the estimation (Dugenne, 2017). To overcome this issue, Hunter-Cevera et al. (2014) performed a dilution experiment to estimate the selective grazing rates. During the OSCAHR campaign, the study of the diel variation of cell size distribution was limited to the warm boundary surface waters based on the assumption that the picophytoplankton populations presented the same cellular properties across this hydrographical province. Tracking of coherent time series in a particular zone based on an adaptive Lagrangian approach might be considered. That was the plan for OSCAHR, but the bad weather conditions 
prevented it. The production estimates presented in this study rely on $\mathrm{C}$ conversions based on cell size, whereas many production estimates are still based on $\mathrm{Chl} a$ to $\mathrm{C}$ conversion factors. Direct integration of growth rates in biogeochemical models (Cullen et al., 1993) and comparison to C-based productivity models (Westberry et al., 2008) should be envisaged for a better assessment of the biogeochemical contribution of picocyanobacteria in oligotrophic ecosystems. Our estimates of specific growth rates and associated apparent production provide new insight into Prochlorococcus and Synechococcus population dynamics and will allow better understanding and quantifying of their respective biogeochemical and ecological contributions in oligotrophic ecosystems, where they play a major role.

\section{Conclusions}

The scientific objectives of the OSCAHR (Observing Submesoscale Coupling At High Resolution) project were to characterize a fine-scale (submesoscale) dynamical structure and to study its influence on the distribution of biogenic elements and the structure and dynamics of the first trophic levels associated with it. The methodology included the use of novel platforms of observation for sampling the ocean surface layer at a high spatial and temporal frequency. A new version of an automated flow cytometer optimized for small and dim cells was installed and tested for real-time, high-throughput sampling of phytoplankton functional groups, from micro-phytoplankton down to picocyanobacteria (including Prochlorococcus). The cruise strategy utilized an adaptive approach based on both satellite and numerical modeling data to identify a dynamical feature of interest and to track its evolution. We have demonstrated that subsurface cold waters reached the surface in the center of a cyclonic recirculation into the Ligurian subbasin. These nutrient-rich upwelled waters induced an increase in Chl $a$ concentration, and associated primary production, in the center of the structure, whereas surrounding warm and oligotrophic boundary waters remained less productive. The phytoplankton community structure was dominated in terms of abundance by Prochlorococcus, Synechococcus, and pico- and nano-eukaryotes, respectively. The phytoplankton community structure was determined from optical properties measured by flow cytometry, which is an ataxonomic technique (except for some specific genus such as Prochlorococcus and Synechococcus). Optical microscope examination of samples might add interesting information, but according to the weak abundance of microphytoplankton (MicroE $\approx 20$ cells cm$^{-3}$ and MicroHighFLO $<$ 5 cells $\mathrm{cm}^{-3}$, with $10 \mu \mathrm{m}<$ MicroE ESD $<20 \mu \mathrm{m}$ and MicroHighFLO ESD $>20 \mu \mathrm{m}$ ) and the small size of nanoeukaryote cells observed (ESD $=4.1 \pm 0.5 \mu \mathrm{m}$ ), a microscopic examination would also have been limited in resolution and quantification. Prochlorococcus and Synechococcus abundances exhibited an opposite distribution throughout cold and warm surface waters, with dominance of Prochlorococcus in cold core waters and of Synechococcus in warm boundary waters. These shifts fitted perfectly with the short-term transitions when passing through one water type to another. The study of the fine-scale vertical distribution of Prochlorococcus and Synechococcus showed that the dominance of Prochlorococcus vs. Synechococcus in cold core waters was closely linked to the upwelled subsurface waters. Coupling a cell's optical properties and physical properties appears to be a valuable approach for characterizing the origin of distinct surface water types.

The OSCAHR campaign perfectly encompasses the new opportunity offered by coupling fine-scale vertical and horizontal physical measurements, remote sensing, modeled data, in situ AFCM and biogeochemistry using an innovative adaptive sampling strategy, in order to deeply understand the fine-scale dynamics of the phytoplankton community structure. The unprecedented spatial and temporal resolution obtained thanks to the latest advances in AFCM deployment allowed us to clearly demonstrate the preponderant role of physical fine-scale processes in the phytoplankton community structure distribution. For the first time, using this new model of Cytobuoy commercial AFCM, we were able to fully resolve Prochlorococcus and Synechococcus picocyanobacteria, the smallest photoautotrophs on Earth, which play a major role in widespread ocean oligotrophic areas. Finally, single-cell analysis of well-defined Prochlorococcus and Synechococcus functional groups associated with a size structure population matrix model provided some valuable indications of the daily dynamics of these populations. Primary productivity estimates of these two major phytoplankton species obtained by this model are essential for better understanding the contribution of picocyanobacteria to biological productivity. This study encourages the continuation and improvement of such a strategy to biogeochemically quantify the contribution of such fine-scale structures in the global ocean. Finally, repeated surveys of the phytoplankton community structure using this kind of combined approach will allow a better assessment of the impact of climate change and anthropogenic forcings. This is particularly of importance in the Mediterranean Sea, which is a biodiversity hotspot under intense pressure from anthropogenic impacts and already one of the most impacted seas in the world (Lejeusne et al., 2010).

Data availability. Standardized, validated and interoperable OSCAHR metadata and data are available through the SeaDataNet PanEuropean infrastructure for ocean and marine data management. The detailed metadata (based upon the ISO19139 standards) created by Doglioli et al. (2018) are available through the Common Data Index (CDI) service. These metadata are tied to the OSCAHR flow cytometry dataset after adopting and creating a flow cytometry common vocabulary. The data can be requested and downloaded 
through the SeaDataNet portal in Ocean Data View ASCII (ODV) format.

Supplement. The supplement related to this article is available online at: https://doi.org/10.5194/bg-15-1579-2018-supplement.

Competing interests. The authors declare that they have no conflict of interest.

Acknowledgement. We thank Anne Petrenko, Louise Rousselet, Alain De Verneil, Christophe Yohia and Christelle Pinazo for modeling outputs. We also thank Nicole Garcia for Chl $a$ measurements. Special thanks go to the DT-INSU people from la Seyne sur Mer, and in particular to Malika Oudia for her help in administration work and Céline Heyndrickx and Frédéric Le Moal for their technical support. Genavir and in particular Julien Fenouil are acknowledged for providing and assisting us with the MVP. MVP and the associated captors were brought by IFREMER and LOPB with co-funding by the Centre Européen de Technologies Sous-Marine (CETSM - Contrat de Projet Etat Région 2007-2013 en PACA) and the French ANR FOCEA (project ANR-09-CEXC006-01 to M. Zhou and F. Carlotti). We also thank J. Thomas Farrar (MIT) for his suggestions on the cruise strategy, Alain Lefèbvre (IFREMER) for the Pocket FerryBox, and Frédéric Partensky for his constructive discussion. The OSCAHR cruise was supported by the MIO "Axes Transverses" program (AT-COUPLAGE), by FEDER fundings (PRECYM flow cytometry platform) and by the following projects: CHROME (PI M. Thyssen, funded by the Excellence Initiative of Aix-Marseille University - A*MIDEX, a French "Investissements d'Avenir" program), SeaQUEST (PI O. Ross, funded by the UE FP7 people), AMICO (PI C. Pinazo, funded by Copernicus - MEDDE French Ministery MDE), and BIOSWOT (PI F. d'Ovidio, funded by TOSCA/CNES). We also thank the captain and crew of the Téthys II research vessel. The project leading to this publication received funding from the European FEDER Fund under project 1166-39417. We thank the support of Labex OT-Med (no. ANR-11-LABX-0061) funded by the French government through the A*MIDEX project (no. ANR-11-IDEX-0001-02).

Edited by: Carol Robinson

Reviewed by: two anonymous referees

\section{References}

Agawin, N. S., Duarte, C. M., and Agusti, S.: Growth and abundance of Synechococcus sp. in a Mediterranean Bay: seasonality and relationship with temperature, Mar. Ecol.-Prog. Ser., 170, 45-53, 1998.

Agustí, S.: Viability and niche segregation of Prochlorococcus and Synechococcus cells across the Central Atlantic Ocean, Aquat. Microb. Ecol., 36, 53-59, 2004.

Aminot, A. and Kérouel, R.: Dosage Automatique des Nutriments Dans Les Eaux Marines: Méthodes en Flux Continu, Edition Quae, Ifremer, Plouzané, France, 2007.
André, J. M., Navarette, C., Blanchot, J., and Radenac, M. H.: Picophytoplankton dynamics in the equatorial Pacific: growth and grazing rates from cytometric counts, J. Geophys. Res., 104, 3369-3380, https://doi.org/10.1029/1998JC900005, 1999.

Astraldi, M. and Gasparini, G. P.: The seasonal characteristics of the circulation in the north Mediterranean basin and their relationship with the atmospheric-climatic conditions, J. Geophys. Res., 97, 9531-9540, https://doi.org/10.1029/92JC00114, 1992.

Astraldi, M. and Gasparini, G. P.: The seasonal and interannual variability in the Ligurian-Provencal Bassin, in: Seasonal and interannual variability of the Western Mediterranean Sea, edited by: La Violette, P. E., Coast. Estuar. Stud., 46, 93-114, 1994.

Barton, A. D., Dutkiewicz, S., Flierl, G., Bragg, J., and Follows, M. J.: Patterns of Diversity in Marine Phytoplankton, Science, 327, 1509-1511, https://doi.org/10.1126/science.1184961, 2010.

Bianchi, C. N. and Morri, C.: Marine biodiversity of the Mediterranean Sea: situation, problems and prospects for future research, Mar. Pollut. Bull., 40, 367-376, 2000.

Binder, B. J. and Chisholm, S. W.: Cell cycle regulation in marine Synechococcus sp. Strains, Appl. Environ. Microb., 61, 708-717, 1995.

Binder, B. J., Chisholm, S. W., Olson, R. J., Frankel, S. L., and Worden, A. Z.: Dynamics of picophytoplankton, ultraphytoplankton and bacteria in the central equatorial Pacific, Deep-Sea Res. Pt. II, 43, 907-931, 1996.

Blanchot, J. and Rodier, M.: Picophytoplankton abundance and biomass in the western tropical Pacific Ocean during the 1992 El Niño year: results from flow cytometry, Deep-Sea Res. Pt. I, 43, 877-895, 1996.

Campbell, L. and Vaulot, D.: Photosynthetic picoplankton community structure in the subtropical North Pacific Ocean near Hawaii (station ALOHA), Deep-Sea Res. Pt. I, 40, 2043-2060, 1993.

Campbell, L., Nolla, H. A., and Vaulot, D.: The importance of Prochlorococcus to community structure in the central North Pacific Ocean, Limnol. Oceanogr., 39, 954-961, https://doi.org/10.4319/lo.1994.39.4.0954, 1994.

Campbell, L., Liu, H., Nolla, H. A., and Vaulot, D.: Annual variability of phytoplankton and bacteria in the subtropical North Pacific Ocean at Station ALOHA during the 1991-1994 ENSO event, Deep-Sea Res. Pt. I, 44, 167-192, 1997.

Chisholm, S. W., Frankel, S. L., Goericke, R., Olson, R. J., Palenik, B., Waterbury, J. B., West-Johnsrud, L., and Zettler, E. R.: Prochlorococcus marinus nov. gen. nov. sp.: an oxyphototrophic marine prokaryote containing divinyl chlorophyll a and b, Arch. Microbiol., 157, 297-300, 1992.

Claustre, H., Kerhervé, P., Marty, J. C., Prieur, L., Videau, C., and Hecq, J.-H.: Phytoplankton dynamics associated with a geostrophic front: ecological and biogeochemical implications, J. Mar. Res., 52, 711-742, 1994.

Claustre, H., Morel, A., Babin, M., Cailliau, C., Marie, D., Marty, J. C., Tailliez, D., and Vaulot, D.: Variability in particle attenuation and chlorophyll fluorescence in the tropical Pacific: scales, patterns, and biogeochemical implications, J. Geophys. Res., 104, 3401-3422, https://doi.org/10.1029/98JC01334, 1999.

Clayton, S., Dutkiewicz, S., Jahn, O., and Follows, M. J.: Dispersal, eddies, and the diversity of marine phytoplankton: Phytoplankton diversity hotspots, Limnol. Oceanogr., 3, 182-197, https://doi.org/10.1215/21573689-2373515, 2013. 
Clayton, S., Nagai, T., and Follows, M. J.: Fine scale phytoplankton community structure across the Kuroshio Front, J. Plankton Res., 36, 1017-1030, https://doi.org/10.1093/plankt/fbu020, 2014.

Cotti-Rausch, B. E., Lomas, M. W., Lachenmyer, E. M., Goldman, E. A., Bell, D. W., Goldberg, S. R., and Richardson, T. L.: Mesoscale and sub-mesoscale variability in phytoplankton community composition in the Sargasso Sea, Deep-Sea Res. Pt. I, 110, 106-122, https://doi.org/10.1016/j.dsr.2015.11.008, 2016.

Cullen, J. J., Geider, R. J., Ishizaka, J., Kiefer, D. A., Marra, J., Sakshaug, E., and Raven, J. A.: Toward a general description of phytoplankton growth for biogeochemical models, in: Towards a Model of Ocean Biogeochemical Processes, Springer, Berlin, Heidelberg, 153-176, 1993.

De La Rocha, C. L. and Passow, U.: Factors influencing the sinking of POC and the efficiency of the biological carbon pump, Deep-Sea Res. Pt. II, 54, 639-658, https://doi.org/10.1016/j.dsr2.2007.01.004, 2007.

Denman, K., Okubo, A., and Platt, T.: The chlorophyll fluctuation spectrum in the sea, Limnol. Oceanogr., 22, 1033-1038, https://doi.org/10.4319/1o.1977.22.6.1033, 1977.

De Vargas, C., Audic, S., Henry, N., Decelle, J., Mahe, F., Logares, R., Lara, E., Berney, C., Le Bescot, N., Probert, I., Carmichael, M., Poulain, J., Romac, S., Colin, S., Aury, J.M., Bittner, L., Chaffron, S., Dunthorn, M., Engelen, S., Flegontova, O., Guidi, L., Horak, A., Jaillon, O., Lima-Mendez, G., Luke, J., Malviya, S., Morard, R., Mulot, M., Scalco, E., Siano, R., Vincent, F., Zingone, A., Dimier, C., Picheral, M., Searson, S., Kandels-Lewis, S., Tara Oceans Coordinators, Acinas, S. G., Bork, P., Bowler, C., Gorsky, G., Grimsley, N., Hingamp, P., Iudicone, D., Not, F., Ogata, H., Pesant, S., Raes, J., Sieracki, M. E., Speich, S., Stemmann, L., Sunagawa, S., Weissenbach, J., Wincker, P., Karsenti, E., Boss, E., Follows, M., Karp-Boss, L., Krzic, U., Reynaud, E. G., Sardet, C., Sullivan, M. B., and Velayoudon, D.: Eukaryotic plankton diversity in the sunlit ocean, Science, 348, 1261605, https://doi.org/10.1126/science.1261605, 2015.

Doglioli, A. M.: OSCAHR cruise, RV Téthys II, https://doi.org/10.17600/15008800, 2015.

Doglioli, A. M., Nencioli, F., Petrenko, A. A., Fuda, J.L., Rougier, G., and Grima, N.: A software package and hardware tools for in situ experiments in a Lagrangian reference frame, J. Atmos. Ocean. Tech., 30, 1945-1950, https://doi.org/10.1175/JTECH-D-12-00183.1, 2013.

Doglioli, A. M., Grégori, G., Marrec, P., Dugenne, M., Della Penna, A., Bhairy, N., Cariou, T., Hélias Nunige, S., Lahbib, S., Rougier, G., Wagener T., and Thyssen, M.: Observing Submesoscale Coupling At High Resolution (OSCAHR), available at: http://seadatanet.maris2.nl/v_cdi_v3/print_wfs.asp? n_code $=2632884$, last access date: 7 March 2018 .

D'Ortenzio, F. and Ribera d'Alcalà, M.: On the trophic regimes of the Mediterranean Sea: a satellite analysis, Biogeosciences, 6, 139-148, https://doi.org/10.5194/bg-6-139-2009, 2009.

D’Ovidio, F., De Monte, S., Alvain, S., Dandonneau, Y., and Lévy, M.: Fluid dynamical niches of phytoplankton types, P. Natl. Acad. Sci. USA, 107, 18366-18370, https://doi.org/10.1073/pnas.1004620107, 2010.

d'Ovidio, F., Della Penna, A., Trull, T. W., Nencioli, F., Pujol, M.-I., Rio, M.-H., Park, Y.-H., Cotté, C., Zhou, M., and Blain, S.: The biogeochemical structuring role of horizon- tal stirring: Lagrangian perspectives on iron delivery downstream of the Kerguelen Plateau, Biogeosciences, 12, 55675581, https://doi.org/10.5194/bg-12-5567-2015, 2015.

Dubinsky, Z. and Stambler, N.: Photoacclimation processes in phytoplankton: mechanisms, consequences, and applications, Aquat. Microb. Ecol., 56, 163-176, https://doi.org/10.3354/ame01345, 2009

Dugenne, M.: Dynamique du phytoplancton en mer Méditerranée: Approches par mesures à haute fréquence, modélisation, et statistiques bayésiennes, PhD Thesis, Aix Marseille Université, available at: http://www.theses.fr/s137171 (last access: 7 March 2018), 2017.

Dugenne, M., Thyssen, M., Nerini, D., Mante, C., Poggiale, J.-C., Garcia, N., Garcia, F., and Grégori, G. J.: Consequence of a sudden wind event on the dynamics of a coastal phytoplankton community: an insight into specific population growth rates using a single cell high frequency approach, Front. Microbiol., 5, 485, https://doi.org/10.3389/fmicb.2014.00485, 2014.

DuRand, M. D., Olson, R. J., and Chisholm, S. W.: Phytoplankton population dynamics at the Bermuda Atlantic Time-series station in the Sargasso Sea, Deep-Sea Res. Pt. II, 48, 1983-2003, 2001.

Estrada, M.: Primary production in the northwestern Mediterranean, Sci. Mar., 60, 55-64, 1996.

Falkowski, P. G. and Ziemann, D.: Role of eddy pumping in enhancing primary production in the ocean, Nature, 352, 55-58, 1991.

Falkowski, P. G., Barber, R. T., and Smetacek, V.: Biogeochemical controls and feedbacks on ocean primary production, Science, 281, 200-206, 1998.

Farrant, G. K., Doré, H., Cornejo-Castillo, F. M., Partensky, F., Ratin, M., Ostrowski, M., Pitt, F. D., Wincker, P., Scanlan, D. J., Iudicone, D., Acinas, S. G., and Garczarek, L.: Delineating ecologically significant taxonomic units from global patterns of marine picocyanobacteria, P. Natl. Acad. Sci. USA, 113, 33653374, https://doi.org/10.1073/pnas.1524865113, 2016.

Ferrier-Pages, C. and Rassoulzadegan, F.: Seasonal impact of the microzooplankton on pico-and nanoplankton growth rates in the northwest Mediterranean Sea, Mar. Ecol.-Prog. Ser., 108, 283294, 1994.

Field, C. B.: Primary production of the biosphere: integrating terrestrial and oceanic components, Science, 281, 237-240, https://doi.org/10.1126/science.281.5374.237, 1998.

Garczarek, L., Dufresne, A., Rousvoal, S., West, N. J., Mazard, S., Marie, D., Claustre, H., Raimbault, P., Post, A. F., Scanlan, D. J., and Partensky, F.: High vertical and low horizontal diversity of Prochlorococcus ecotypes in the Mediterranean Sea in summer: Diversity of Prochlorococcus in the Mediterranean Sea, FEMS Microbiol. Ecol., 60, 189-206, https://doi.org/10.1111/j.15746941.2007.00297.x, 2007.

Gaube, P., Chelton, D. B., Strutton, P. G., and Behrenfeld, M. J.: Satellite observations of chlorophyll, phytoplankton biomass, and Ekman pumping in nonlinear mesoscale eddies, J. Geophys. Res., 118, 6349-6370, https://doi.org/10.1002/2013JC009027, 2013.

Girault, M., Arakawa, H., Barani, A., Ceccaldi, H. J., Hashihama, F., Kinouchi, S., and Gregori, G.: Distribution of ultraphytoplankton in the western part of the North Pacific subtropical gyre during a strong La Niña condition: relationship with 
the hydrological conditions, Biogeosciences, 10, 5947-5965, https://doi.org/10.5194/bg-10-5947-2013, 2013a.

Girault, M., Arakawa, H., and Hashihama, F.: Phosphorus stress of microphytoplankton community in the western subtropical North Pacific, J. Plankton Res., 35, 146-157, https://doi.org/10.1093/plankt/fbs076, 2013b.

Goericke, R. and Welschmeyer, N. A.: The marine prochlorophyte Prochlorococcus contributes significantly to phytoplankton biomass and primary production in the Sargasso Sea, Deep-Sea Res. Pt. I, 40, 2283-2294, 1993.

Gómez, F. and Gorsky, G.: Annual microplankton cycles in Villefranche Bay, Ligurian subbasin, NW Mediterranean, J. Plankton Res., 25, 323-339, 2003.

Goutx, M., Guigue, C., Aritio, D., Ghiglione, J. F., Pujo-Pay, M., Raybaud, V., Duflos, M., and Prieur, L.: Short term summer to autumn variability of dissolved lipid classes in the Ligurian sea (NW Mediterranean), Biogeosciences, 6, 1229-1246, https://doi.org/10.5194/bg-6-1229-2009, 2009.

Graff, J. R., Milligan, A. J., and Behrenfeld, M. J.: The measurement of phytoplankton biomass using flow-cytometric sorting and elemental analysis of carbon: phytoplankton carbon analysis, Limnol. Oceanogr.-Meth., 10, 910-920, https://doi.org/10.4319/lom.2012.10.910, 2012.

Hunter-Cevera, K. R., Neubert, M. G., Solow, A. R., Olson, R. J., Shalapyonok, A., and Sosik, H. M.: Diel size distributions reveal seasonal growth dynamics of a coastal phytoplankter, P. Natl. Acad. Sci. USA, 111, 9852-9857, https://doi.org/10.1073/pnas.1321421111, 2014.

IPCC: Climate Change 2013: The Physical Science Basis. Contribution of Working Group I to the Fifth Assessment Report of the Intergovernmental Panel on Climate Change, edited by: Stocker, T. F., Qin, D., Plattner, G.-K., Tignor, M., Allen, S. K., Boschung, J., Nauels, A., Xia, Y., Bex, V., and Midgley, P. M., Cambridge University Press, Cambridge, UK and New York, NY, USA, 1535 pp., 2013.

Jacquet, S., Partensky, F., Lennon, J.-F., and Vaulot, D.: Diel patterns of growth and division in marine picoplankton in culture, J. Phycol., 37, 357-369, 2001.

Lejeusne, C., Chevaldonné, P., Pergent-Martini, C., Boudouresque, C. F., and Pérez, T.: Climate change effects on a miniature ocean: the highly diverse, highly impacted Mediterranean Sea, Trends Ecol. Evol., 25, 250-260, https://doi.org/10.1016/j.tree.2009.10.009, 2010.

Lévy, M. and Martin, A. P.: The influence of mesoscale and submesoscale heterogeneity on ocean biogeochemical reactions: Influence of heterogeneity, Global Biogeochem. Cy., 27, 1139-1150, https://doi.org/10.1002/2012GB004518, 2013.

Lévy, M., Klein, P., and Treguier, A.-M.: Impact of sub-mesoscale physics on production and subduction of phytoplankton in an oligotrophic regime, J. Mar. Res., 59, 535-565, 2001.

Lévy, M., Bopp, L., Karleskind, P., Resplandy, L., Ethe, C., and Pinsard, F.: Physical pathways for carbon transfers between the surface mixed layer and the ocean interior: Physical Carbon Fluxes, Global Biogeochem. Cy., 27, 1001-1012, https://doi.org/10.1002/gbc.20092, 2013.

Lévy, M., Jahn, O., Dutkiewicz, S., and Follows, M. J.: Phytoplankton diversity and community structure affected by oceanic dispersal and mesoscale turbulence, Limnol. Oceanogr., 4, 67-84, https://doi.org/10.1215/21573689-2768549, 2014.
Lévy, M., Jahn, O., Dutkiewicz, S., Follows, M. J., and d'Ovidio, F.: The dynamical landscape of marine phytoplankton diversity, J. R. Soc. Interface, 12, 20150481 , https://doi.org/10.1098/rsif.2015.0481, 2015.

Liu, H., Nolla, H. A., and Campbell, L.: Prochlorococcus growth rate and contribution to primary production in the equatorial and subtropical North Pacific Ocean, Aquat. Microb. Ecol., 12, 3947, 1997.

Mahadevan, A.: The impact of submesoscale physics on primary productivity of plankton, Annu. Rev. Mar. Sci., 8, 161-184, https://doi.org/10.1146/annurev-marine-010814-015912, 2016.

Malanotte-Rizzoli, P., Artale, V., Borzelli-Eusebi, G. L., Brenner, S., Crise, A., Gacic, M., Kress, N., Marullo, S., Ribera d'Alcalà, M., Sofianos, S., Tanhua, T., Theocharis, A., Alvarez, M., Ashkenazy, Y., Bergamasco, A., Cardin, V., Carniel, S., Civitarese, G., D’Ortenzio, F., Font, J., Garcia-Ladona, E., Garcia-Lafuente, J. M., Gogou, A., Gregoire, M., Hainbucher, D., Kontoyannis, H., Kovacevic, V., Kraskapoulou, E., Kroskos, G., Incarbona, A., Mazzocchi, M. G., Orlic, M., Ozsoy, E., Pascual, A., Poulain, P.-M., Roether, W., Rubino, A., Schroeder, K., Siokou-Frangou, J., Souvermezoglou, E., Sprovieri, M., Tintoré, J., and Triantafyllou, G.: Physical forcing and physical/biochemical variability of the Mediterranean Sea: a review of unresolved issues and directions for future research, Ocean Sci., 10, 281-322, https://doi.org/10.5194/os-10-281-2014, 2014.

Marañón, E.: Cell size as a key determinant of phytoplankton metabolism and community structure, Annu. Rev. Mar. Sci., 7, 241-264, https://doi.org/10.1146/annurev-marine010814-015955, 2015.

Marañón, E., Behrenfeld, M. J., González, N., Mouriño, B., and Zubkov, M. V.: High variability of primary production in oligotrophic waters of the Atlantic Ocean: uncoupling from phytoplankton biomass and size structure, Mar. Ecol.-Prog. Ser., 257, 1-11, 2003.

Martin, A. P., Lévy, M., van Gennip, S., Pardo, S., Srokosz, M., Allen, J., Painter, S. C., and Pidcock, R.: An observational assessment of the influence of mesoscale and submesoscale heterogeneity on ocean biogeochemical reactions: Biogeochemical eddy reaction, Global Biogeochem. Cy., 29, 1421-1438, https://doi.org/10.1002/2015GB005129, 2015.

Marty, J.-C., Chiavérini, J., Pizay, M.-D., and Avril, B.: Seasonal and interannual dynamics of nutrients and phytoplankton pigments in the western Mediterranean Sea at the DYFAMED timeseries station (1991-1999), Deep-Sea Res. Pt. II, 49, 1965-1985, 2002.

Marty, J.-C., Garcia, N., and Raimbault, P.: Phytoplankton dynamics and primary production under late summer conditions in the NW Mediterranean Sea, Deep-Sea Res. Pt. I, 55, 1131-1149, https://doi.org/10.1016/j.dsr.2008.05.001, 2008.

McGillicuddy, D. J.: Mechanisms of physical-biologicalbiogeochemical interaction at the oceanic mesoscale, Annu. Rev. Mar. Sci., 8, 125-159, https://doi.org/10.1146/annurev-marine010814-015606, 2016.

McGillicuddy, D. J., Robinson, A. R., Siegel, D. A., Jannasch, H. W., Johnson, R., Dickey, T. D., McNiel, J., Michaels, A. F., and Knap, A. H.: Influence of mesoscale eddies on new production in the Sargasso Sea, Nature, 394, 263-266, 1998. 
Mella-Flores, D., Mazard, S., Humily, F., Partensky, F., Mahé, F., Bariat, L., Courties, C., Marie, D., Ras, J., Mauriac, R., Jeanthon, C., Mahdi Bendif, E., Ostrowski, M., Scanlan, D. J., and Garczarek, L.: Is the distribution of Prochlorococcus and Synechococcus ecotypes in the Mediterranean Sea affected by global warming?, Biogeosciences, 8, 2785-2804, https://doi.org/10.5194/bg-8-2785-2011, 2011.

Mella-Flores, D., Six, C., Ratin, M., Partensky, F., Boutte, C., Le Corguillé, G., Marie, D., Blot, N., Gourvil, P., Kolowrat, C., and Garczarek, L.: Prochlorococcus and Synechococcus have evolved different adaptive mechanisms to cope with light and UV stress, Front. Microbiol., 3, 285, https://doi.org/10.3389/fmicb.2012.00285, 2012.

Menden-Deuer, S. and Lessard, E. J.: Carbon to volume relationships for dinoflagellates, diatoms, and other protist plankton, Limnol. Oceanogr., 45, 569-579, https://doi.org/10.4319/lo.2000.45.3.0569, 2000.

Michelou, V. K., Lomas, M. W., and Kirchman, D. L.: Phosphate and adenosine-5' -triphosphate uptake by cyanobacteria and heterotrophic bacteria in the Sargasso Sea, Limnol. Oceanogr., 56, 323-332, https://doi.org/10.4319/lo.2011.56.1.0323, 2011.

Migon, C.: Riverine and atmospheric inputs of heavy metals to the Ligurian Sea, Sci. Total Environ., 138, 289-299, 1993.

Millot, C.: Circulation in the western Mediterranean Sea, J. Marine Syst., 20, 423-442, 1999.

Millot, C. and Taupier-Letage, I.: Circulation in the Mediterranean Sea, The Mediterranean Sea, The Handbook of Environ. Chem., Springer Berlin, Heidelberg, 323-334, 2005.

Miquel, J.-C., Martín, J., Gasser, B., Rodriguez-y-Baena, A., Toubal, T., and Fowler, S. W.: Dynamics of particle flux and carbon export in the northwestern Mediterranean Sea: A two decade time-series study at the DYFAMED site, Prog. Oceanogr., 91, 461-481, https://doi.org/10.1016/j.pocean.2011.07.018, 2011.

Moore, L.: Comparative physiology of Synechococcus and Prochlorococcus: influence of light and temperature on growth, pigments, fluorescence and absorptive properties, Mar. Ecol.Prog. Ser., 116, 259-275, 1995.

Moore, L. R. and Chisholm, S. W.: Photophysiology of the marine cyanobacterium Prochlorococcus: ecotypic differences among cultured isolates, Limnol. Oceanogr., 44, 628-638, https://doi.org/10.4319/1o.1999.44.3.0628, 1999.

Morel, A., Ahn, Y.-H., Partensky, F., Vaulot, D., and Claustre, H.: Prochlorococcus and Synechococcus: a comparative study of their optical properties in relation to their size and pigmentation, J. Mar. Res., 51, 617-649, 1993.

Morel, A., Gentili, B., Chami, M., and Ras, J.: Bio-optical properties of high chlorophyll Case 1 waters and of yellow-substancedominated Case 2 waters, Deep-Sea Res. Pt. I, 53, 1439-1459, https://doi.org/10.1016/j.dsr.2006.07.007, 2006.

Moutin, T. and Prieur, L.: Influence of anticyclonic eddies on the Biogeochemistry from the Oligotrophic to the Ultraoligotrophic Mediterranean (BOUM cruise), Biogeosciences, 9, 3827-3855, https://doi.org/10.5194/bg-9-3827-2012, 2012.

Moutin, T., Thingstad, T. F., Van Wambeke, F., Marie, D., Slawyk, G., Raimbault, P., and Claustre, H.: Does competition for nanomolar phosphate supply explain the predominance of the cyanobacterium Synechococcus?, Limnol. Oceanogr., 47, 15621567, https://doi.org/10.4319/lo.2002.47.5.1562, 2002.
Nezlin, N. P., Lacroix, G., Kostianoy, A. G., and Djenidi, S.: Remotely sensed seasonal dynamics of phytoplankton in the Ligurian Sea in 1997-1999, J. Geophys. Res.-Oceans, 109, C07013, https://doi.org/10.1029/2000JC000628, 2004.

Niiler, P. P.: On the Ekman divergence in an oceanic jet, J. Geophys. Res., 74, 7048-7052, 1969.

Not, F., del Campo, J., Balagué, V., de Vargas, C., and Massana, R.: New insights into the diversity of marine picoeukaryotes, Plos One, 4, e7143, https://doi.org/10.1371/journal.pone.0007143, 2009.

Olson, R. J., Chisholm, S. W., Zettler, E. R., and Armbrust, E. V.: Analysis of Synechococcus pigment types in the sea using single and dual beam flow cytometry, Deep-Sea Res. Pt. I, 35, 425-440, 1988.

Olson, R. J., Chisholm, S. W., Zettler, E. R., Altabet, M. A., and Dusenberry, J. A.: Spatial and temporal distributions of prochlorophyte picoplankton in the North Atlantic Ocean, DeepSea Res. Pt. I, 37, 1033-1051, 1990a.

Olson, R. J., Chisholm, S. W., Zettler, E. R., and Armbrust, E.: Pigments, size, and distributions of Synechococcus in the North Atlantic and Pacific Oceans, Limnol. Oceanogr., 35, 45-58, https://doi.org/10.4319/lo.1990.35.1.0045, 1990b.

Oschlies, A. and Garçon, V.: Eddy-induced enhancement of primary production in a model of the North Atlantic Ocean, Nature, 394, 266-269, 1998.

Partensky, F. and Garczarek, L.: Prochlorococcus: advantages and limits of minimalism, Annu. Rev. Mar. Sci., 2, 305-331, https://doi.org/10.1146/annurev-marine-120308-081034, 2010.

Partensky, F., Blanchot, J., and Vaulot, D.: Differential distribution and ecology of Prochlorococcus and Synechococcus in oceanic waters: a review, in: Marine Cyanobacteria, edited by: Charpy, L. and Larkum, A. W. D., Institute of Oceanography, Monaco, 457475, 1999a.

Partensky, F., Hess, W. R., and Vaulot, D.: Prochlorococcus, a marine photosynthetic prokaryote of global significance, Microbiol. Mol. Biol. R., 63, 106-127, 1999b.

Pascual, A., Ruiz, S., Olita, A., Troupin, C., Claret, M., Casas, B., Mourre, B., Poulain, P.-M., Tovar-Sanchez, A., Capet, A., Mason, E., Allen, J. T., Mahadevan, A., and Tintoré, J.: A Multiplatform Experiment to Unravel Meso- and Submesoscale Processes in an Intense Front (AlborEx), Front. Mar. Sci., 4, 39, https://doi.org/10.3389/fmars.2017.00039, 2017.

Percopo, I., Siano, R., Cerino, F., Sarno, D., and Zingone, A.: Phytoplankton diversity during the spring bloom in the northwestern Mediterranean Sea, Bot. Mar., 54, 243-267, https://doi.org/10.1515/bot.2011.033, 2011.

Petrenko, A. A., Doglioli, A. M., Nencioli, F., Kersalé, M., Hu, Z., and d'Ovidio, F.: A review of the LATEX project: mesoscale to submesoscale processes in a coastal environment, Ocean Dynam., 67, 513, https://doi.org/10.1007/s10236-017-1040-9, 2017.

Pittera, J., Humily, F., Thorel, M., Grulois, D., Garczarek, L., and Six, C.: Connecting thermal physiology and latitudinal niche partitioning in marine Synechococcus, ISME J., 8, 1221-1236, https://doi.org/10.1038/ismej.2013.228, 2014.

Platt, T.: Local phytoplankton abundance and turbulence, Deep-Sea Res., 19, 183-187, https://doi.org/10.1016/00117471(72)90029-0, 1972. 
Ribalet, F., Swalwell, J., Clayton, S., Jiménez, V., Sudek, S., Lin, Y., Johnson, Z. I., Worden, A. Z., and Armbrust, E. V.: Light-driven synchrony of Prochlorococcus growth and mortality in the subtropical Pacific gyre, P. Natl. Acad. Sci. USA, 112, 8008-8012, https://doi.org/10.1073/pnas.1424279112, 2015.

Shalapyonok, A., Olson, R. J., and Shalapyonok, L. S.: Arabian Sea phytoplankton during Southwest and Northeast Monsoons 1995: composition, size structure and biomass from individual cell properties measured by flow cytometry, Deep-Sea Res. Pt. II, 48, 1231-1261, 2001.

Siegel, D. A., Buesseler, K. O., Behrenfeld, M. J., BenitezNelson, C. R., Boss, E., Brzezinski, M. A., Burd, A., Carlson, C. A., D’Asaro, E. A., Doney, S. C., Perry, M. J., Stanley, R. H. R., and Steinberg, D. K.: Prediction of the export and fate of global ocean net primary production: the EXPORTS science plan, Front. Mar. Sci., 3, 22, https://doi.org/10.3389/fmars.2016.00022, 2016.

Sieracki, M. E., Haugen, E. M., and Cucci, T. L.: Overestimation of heterotrophic bacteria in the Sargasso Sea: direct evidence by flow and imaging cytometry, Deep-Sea Res. Pt. I, 42, 1399-1409, 1995.

Simon, N., Barlow, R. G., Marie, D., Partensky, F., and Vaulot, D.: Characterization of oceanic photosynthetic picoeukaryotes by flow cytometry, J. Phycol., 30, 922-935, 1994.

Siokou-Frangou, I., Christaki, U., Mazzocchi, M. G., Montresor, M., Ribera d'Alcalá, M., Vaqué, D., and Zingone, A.: Plankton in the open Mediterranean Sea: a review, Biogeosciences, 7, 15431586, https://doi.org/10.5194/bg-7-1543-2010, 2010.

Skamarock, W. C., Klemp, J. B., Dudhia, J., Gill, D. O., Barker, D. M., Duda, M. G., Huang, X.-Y., Wang, W., and Powers, J. G.: A description of the advanced research WRF version 3, Rep. NCAR/TN-475+STR, 125 pp., Natl. Cent. for Atmos. Res, Boulder, Colorado, available at: https://doi.org/10.5065/ D68S4MVH (last access: 7 March 2018), 2008.

Sosik, H. M., Olson, R. J., Neubert, M. G., Shalapyonok, A., and Solow, A. R.: Growth rates of coastal phytoplankton from time-series measurements with a submersible flow cytometer, Limnol. Oceanogr., 48, 1756-1765, https://doi.org/10.4319/lo.2003.48.5.1756, 2003.

Sournia, A., Brylinski, J. M., Dallot, S., LeCorre, P., Leveau, M., Prieur, L., and Froget, C.: Fronts hydrologiques au large des côtes françaises: Les sites-ateliers de programme Frontal, Oceanol. Acta, 13, 413-438, 1990.
Stambler, N.: Relationships between picophytoplankton and optical properties in the Azores Front region in the Atlantic Ocean, J. Sea Res., 85, 144-154, https://doi.org/10.1016/j.seares.2013.04.016, 2014.

Stern, M. E.: Interaction of a uniform wind stress with a geostrophic vortex, Deep-Sea Res. Oceanogr. Abstr., 12, 355-367, 1965.

Vaillancourt, R. D., Marra, J., Seki, M. P., Parsons, M. L., and Bidigare, R. R.: Impact of a cyclonic eddy on phytoplankton community structure and photosynthetic competency in the subtropical North Pacific Ocean, Deep-Sea Res. Pt. I, 50, 829-847, https://doi.org/10.1016/S0967-0637(03)00059-1, 2003.

Vaulot, D. and Chisholm, S. W.: A simple model of the growth of phytoplankton populations in light/dark cycles, J. Plankton Res., 9, 345-366, 1987.

Vaulot, D. and Marie, D.: Diel variability of photosynthetic picoplankton in the equatorial Pacific, J. Geophys. Res.-Oceans, 104, 3297-3310, https://doi.org/10.1029/98JC01333, 1999.

Vaulot, D., Marie, D., Olson, R. J., and Chisholm, S. W.: Growth of Prochlorococcus, a photosynthetic prokaryote, in the equatorial Pacific Ocean, Science, 268, 1480-1480, 1995.

Vaulot, D., Eikrem, W., Viprey, M., and Moreau, H.: The diversity of small eukaryotic phytoplankton $(\leq 3 \mu \mathrm{m})$ in marine ecosystems, FEMS Microbiol. Rev., 32, 795-820, https://doi.org/10.1111/j.1574-6976.2008.00121.x, 2008.

Warren, J. D.: Zooplankton in the Ligurian Sea: Part I I. Exploration of their physical and biological forcing functions during summer 2000, J. Plankton Res., 26, 1419-1427, https://doi.org/10.1093/plankt/fbh129, 2004.

Waterbury, J. B., Watson, S. W., Valois, F. W., and Franks, D. G.: Biological and ecological characterization of the marine unicellular cyanobacterium Synechococcus, Can. B. Fish Aquat. Sci., 214, 71-120, 1986.

Welschmeyer, N. A.: Fluorometric analysis of chlorophyll a in the presence of chlorophyll $b$ and pheopigments, Limnol. Oceanogr., 39, https://doi.org/10.4319/lo.1994.39.8.1985, 1994.

Westberry, T., Behrenfeld, M. J., Siegel, D. A., and Boss, E.: Carbon-based primary productivity modeling with vertically resolved photoacclimation: carbon-based production model, Global Biogeochem. Cy., 22, GB2024, https://doi.org/10.1029/2007GB003078, 2008.

Worden, A. Z. and Not, F.: Ecology and diversity of picoeukaryotes, in: Microbial Ecology of the Ocean, edited by: Kirchman, D. L., 2nd edition, New York, Wiley-Liss., 159-196, 2008. 